\title{
Environmental Degradation \& Role of Financialisation, Economic Development, Industrialisation and Trade Liberalisation
}

\author{
Muhammad Ali Nasir \\ Huddersfield Business School, United Kingdom \\ Nguyen Phuc Canh \\ School of Banking, University of Economics Ho Chi Minh City, 59C Nguyen Dinh Chieu, \\ District 3, Ho Chi Minh (700000), Vietnam \\ Thi Ngoc Lan Le \\ Queensland University of Technology, Australia
}

\begin{abstract}
This paper is a pioneering endeavour to investigate the determinants of environmental degradation in Australia through a comprehensive framework of EKC and STIRPAT. Specifically, the impacts of multiple factors of socio-economic development including economic growth, trade openness, industrialization, energy consumption on $\mathrm{CO}_{2}$ emissions are analysed. Furthermore, the influences of financial development through different dimensions (financial efficiency, access and depth) in two subsectors (financial markets and institutions) and other proxies of financial development are focused over the period 1980-2014. Empirical results show short as well as long-run differences in the association among the variables. Shortterm bidirectional causality prevails between economic growth, energy consumption, industrialization, and stock market development with carbon dioxide $\left(\mathrm{CO}_{2}\right)$ emissions. However, there is no significant evidence found on EKC. This is due to the long-run positive impact of financial development, energy consumption, and trade openness on $\mathrm{CO}_{2}$ emissions. Interestingly, the industrialization process is found to does not affect $\mathrm{CO} 2$ emissions. Empirical findings provide insight into why the quality of the Australian environment is truncated with frequent and widespread bushfires and suggest policymakers to have selective and strict environmental-friendly strategies to fulfil a sustainable development goal.
\end{abstract}

Keywords: Carbon emissions; EKC; STIRPAT, Industrialization, Population, Economic Development, Trade Openness, Financial development. 


\section{Introduction}

Geographically one of the largest countries in the world, Australia with its unique and precious climate, rich oceans, vast forests and wildlife. Despite, a comparatively small population, the geographical size makes Australia ecologically very important. Unfortunately, the Australian environment is under threat as there have been many landuse changes, habitat fragmentation and degradation, especially continuous bush fires happening recently. Furthermore, the emissions of Green House Gasses (GHGs) particularly $\mathrm{CO}_{2}$ is one of the curial cause of rising global temperatures, also been quite high in Australia in per capita terms. The ecosystems have rather more restricted capacity to manage different kinds of pressures compared to human systems. For example, the too big and too fast bush fires have been destroying climatically suitable areas for different precious species making it difficult for them to follow their natural migration patterns. The year 2019 is considered as the worst year on a record since 1950 for bushfire risk, and by the beginning of 2020, bushfires have destroyed approximately six million hectares, hundreds of homes and killed thousands of people and billions of wildlife losses. According to NASA (2020), GHG emissions are one of the major causes of climate change and global warming. As a consequence, climate change results in bushfires in Australia (Phillips and Nogrady, 2020). This misery in the form of bushfires raises the crucial question about climate change and environmental degradation in Australia and its causes. Specifically, what are the contributing factors to the increasing environmental degradation and emissions in Australia? Furthermore, climate change is a global issue that poses existential challenges to the human civilisation requiring an appropriate policy response from the governments and stakeholders. The responsibility of saving the world from the deterioration of environment particularly falls upon the countries which are the major emitters of GHGs, including Australia with one of the world highest per capita emissions. Australia has not always been at the forefront of the fight against climate change, for instance, it had hesitated to ratify the Kyoto Protocol and to end fossil fuel subsidies. However, it is a signatory of Conference of Parties (COP:21) held in Paris in 2015 and for that reason has committed herself to reductions in emissions. The Australian government, although, has expressed strong commitments to reduce emissions with the target of 50-52 per cent emissions reduction. However, curbing carbon emissions would mean to have implications for economic growth and therefore it 
may cause the reluctancy to honour the COP21 commitments. Therefore, it is important to explore the nexus between economic growth, financial development and other relevant socio-economic factors and environmental degradation in Australia. Concomitantly, a study on driving factors affecting climate change and causing the environmental degradation conducted in the Australian context has the prospect of shedding some light and draw crucial policy lessons to tackle the existentially important environmental challenges.

The remarkable development of the Australian economy is often associated with higher levels of FDI and trade openness as compared to its counterparts. The GDP figures indicate a resilient and stable growth over many decades that has enabled Australia to stand among the 20 largest economies i.e. G-20. Despite the fact that this is a success story in terms of economic growth, it is vital to see in the environmental context. Due to the adverse implications of unsustainable economic growth for the environment, there has been increasing emphasis to take an inclusive and more sustainable approach to economic development. Environmental damage by the emissions of greenhouse gases has led to calls for renewable energy as a substitute source to reduce $\mathrm{CO}_{2}$ emissions, particularly in the context of increasing global demand. Increasing emissions are also likely to come from trade liberalisation, where taking advantage of globalization, the rich nations cut the production of the pollution-intensive goods (Pham et al 2020). As a result, the treaties associated with the increase in renewable/green energy in total energy consumption and through energy innovation, all of which are subject to the governor of environmental degradations, have an attractive debate among scholars (Lorente and Álvarez-herránz et al.,2017 and Álvarez-herranz, 2016). Nevertheless, the empirical evidence nexus among FDI, consumption of energy and economic growth as well as nexus between FDI and environmental degradation suggest inconclusive results (Nasir et al. 2019, Pham et al. 2020). Therefore, the Australian context requires further insight and research to examine the effects of FDI inflows and trade openness on the environment.

Theoretically, socio-economic activities are the main cause of environmental degradation (Minh et al., 2020). The EKC implies that there is an inverted-U shaped association prevails between environmental degradation and the level of income i.e. growth of the economy (Kuznets, 1955, See Dinda (2004) for the survey on the EKC). Whereas, the STIRPAT model explains in more detail with economic development, population, 
technology as main drivers of environmental degradation (Dietz and Rosa, 1997). Furthermore, similar to the economy - environment nexus, there are contrasting views regarding the role of financial development in environmental degradation. On the negative view, the growth of the financial market opens more credits lines to customers who then spend on "large-ticket" items, such as automobiles and machinery, which consume a large amount of energy. Besides, financial development is closely associated with the expansion of the stock market which is also accounted as a vital sign of economic progress and opens more opportunities for customers to access to financial capital at lower borrowing costs, through which more plants and machines are constructed, all of which boost the demand for energy. A higher degree of energy consumption accompanies higher $\mathrm{CO}_{2}$ emissions and may result in environmental degradation. The positively supporting view suggests that the financial development, i.e. resourceful inflows of domestic credits to private sectors or stock market capitalization, provide debt and equity to the host country to develop green and renewable energy projects (Dasgupta et al., 2004). Therefore, financial development assists as an impetus for the technology innovation to reduce the energy use (Alfaro et al., 2004; Hermes and Lensink, 2003) and simultaneously enhanced lending to the development of green-energy industry and hence increased usage of the green energy. Hence, the empirical evidence on the impact of financial development on the degradation of the environment is contrasting. A point also worth emphasising here is the financial development and how it is measured. Often researchers have only looked at one aspect of the financial sector, yet, it is crucial to take a comprehensive approach to the measurement of financial development to fully comprehend its impact (Nasir, et al 2019). Contextualising on the severity on climate change in Australia, our study examines the implications of economic growth (real income, trade openness, industrialization), financial development (overall financial development, financial market access, financial institution efficiency, financial market development, financial market efficiency) with three dimensions (financial efficiency, financial access and financial depth) and consumption of energy for Australian emissions of CO2 from 1980 to 2014. In terms of its analytical and theoretical framework, this study is based on two imperative theories in environmental economics, the EKC and the STIRPAT, developed by Dietz and Rosa (1997). The EKC implies that there is an inverted$\mathrm{U}$ shaped association prevails in the relationship between environmental degradation and levels of income in an economy (Kuznets, 1955), Whereas, the STIRPAT model 
explains in more detail the role of economic development, population, technology as main drivers of environmental degradation (Dietz and Rosa, 1997). Therefore, these two models manifest the underlying factors contributing to environmental degradation. The results from the models could lead to policy implication for the Australian government whether financial development, population, and economic growth increase or mitigate the environmental degradation, and whether the technology could be a solution to improve the environmental degradation and reduce GHGs. The key empirical findings obtained from the application of both frameworks suggest that there are causal relationships between the growth of the economy, consumption of energy, industrialization, and stock market development with emissions of $\mathrm{CO}_{2}$ in the short run. The growth of economy does not confirm the presence of the EKC. In contrast, the financial development, consumption of energy and trade liberalisation have a long-run positive effect on the $\mathrm{CO}_{2}$ emissions. Interestingly, the industrialization process is found to has no significant effect on $\mathrm{CO}_{2}$ emissions. Our findings contribute to the debate on the implications of socio-economic and financial development for the environment by particularly focusing on the Australian case which has suffered from severe ecological degradation in recent years.

The rest of the paper is organized as follows: In $\S 2$ we critically discuss the literature concerning $\mathrm{CO}_{2}$ emissions and its contributing factors, particularly the role of economic and financial development. $§ 3$ sets out the methodology and data. Subsequently, $§ 4$ presents and discuss empirical results whereas $\S 5$ concludes and provide implications for policymaking.

\section{Economic Development \& Environmental Degradation}

Considering the obvious importance of the subject, several studies investigated the implications of economic development for environmental degradation. Kalyoncu et al. (2013) reviewed the nexus between energy and growth devised three principal viewpoints. First, highlights that the energy is an input of production process and therefore it formulates a causal relationship between energy usage and growth of the economy (Stern and Cleveland, 2004). Second, that the causality runs from the development of the economy to consumption of energy (Toman and Jemelkova, 2003; Aziz, 2011) and there prevails an EKC. That is when income level (a proxy of economic 
development) increases, environmental pollution increases but then decreases after peaking a threshold. Finally, the third point of view presents that the association is a bidirectional way, which means economic development's effect on consumption of energy and vice versa (Aziz, 2011). Existing literature fails to establish any consensus since there are a number of crucial contextual factors to account for as well as idiosyncratic characteristics of various countries. For example, Shahbaz and Sinha, (2019) confirmed the inconclusiveness in the relation between income and CO2 emissions (EKC) due to the discrepancies regarding the contexts, various periods, samples, and methodologies in the existing literature.

The fast growth of the economy is associated with increasing energy demand, especially in the emerging economies (Ouyang and Lin, 2017) since many emerging economies are growing at a faster rate and as economies grow so does the energy demand. Therefore, the economic activity plays the part of the driving factor for the increase in $\mathrm{CO}_{2}$ emission (Ouyang and Lin, 2015; Nasir et al 2019). The study by Ghosh and Kanjilal (2014) reported a causal relationship (unidirectional) between consumption of energy consumption economic activity and from economic growth to urbanization in India, whereas the stable growth of Chinese economy is found to increase the emissions of $\mathrm{CO}_{2}$ (Ouyang and Lin, 2017; Ouyang and Lin (2015), which supports the EKC model. In their analysis on implications of the growth of economy and consumption of energy for $\mathrm{CO}_{2}$ emissions through 17 countries in the South and Southeast Asian region, Behera and Dash (2017) argue in favour of EKC and report that the consumption of energy in middleincome countries is noticeably snowballing the $\mathrm{CO}_{2}$ emission, and resulting in a greenhouse gas problem. The EKC theory is found to be applicable to a larger sample. For example, in the panel data of 136 countries which are divided into low, middle and high incomes (OECD and non-OECD countries), Mamun et al. (2014) reported existence of the EKC in all regions except for high-income OECD countries. Furthermore, the Population growth is also associated with an increased while economic liberalization is linked to a reduction in $\mathrm{CO}_{2}$ emissions.

There is also a strand of literature that supports the bidirectional relationship between economic growth, consumption of energy and $\mathrm{CO}_{2}$ emissions. It has been argued that a highly developed economy and then rapid urbanization drive the high demand for private vehicles and transportation, contributing to a growing level of $\mathrm{CO}_{2}$ emissions. The greater 
the economy is likely to connect with the extended transportation system and higher energy consumption as higher economic development requires more energy usage (Halicioglu, 2009). Saboori et al. (2014) reported a positive association between the growth of the economy, consumption of energy and $\mathrm{CO}_{2}$ emissions in OECD countries which have experienced remarkable economic growth. Salahuddin et al. (2015) conduct a study on the Gulf Cooperation Council (GCC) countries. These economies have also shown fast growth and contribute to approximately $8 \%$ of the world's carbon emissions. Their empirical results indicated a long-run association between overall energy consumption as well as by the road sector, growth of economy and emissions. Similarly, Saboori and Sulaiman, (2013) find bidirectional Granger causality in ASEAN countries. Specially, they found a long-run causal relationship between growth, $\mathrm{CO}_{2}$ emissions, and electricity consumption in Indonesia, Malaysia and Philippine, while the short-run causal relationship was found between the growth of economy and $\mathrm{CO}_{2}$ emissions for Indonesia, Singapore and Thailand, and consumption of energy and $\mathrm{CO}_{2}$ emissions in Malaysia and Singapore.

There is also a considerable amount of evidence (see e.g. Pao et al., 2011; Acaravci and Ozturk, 2010; Özokcu and Özdemir, 2017) suggesting that neither environmental pollution nor consumption of energy cause growth of the economy. Also, Begum et al. (2015) reported a U-shape relationship (i.e. or EKC ) on the effect of economic and population growth, consumption of energy on $\mathrm{CO}_{2}$ emissions in Malaysia. Specifically, the $\mathrm{CO}_{2}$ emissions decline with an increase in GDP for the period of 1970-1980, but after 1980 , the $\mathrm{CO}_{2}$ increase is caused by the growth of GDP. Most of the existing on the subject are either on a single but different country or multiples countries. For example, on China (Ouyang and Lin, 2017; Ouyang and Lin, 2014; Ouyang and Lin, 2015); Turkey (Acaravci Ozturk, 2010); Brazil (Pao and Tsai, 2011); Russia (Pao et al., 2011); Malaysia (Begum et al., 2015); India (Ghosh, 2010); Australia (Salahuddin and Alam, 2015); Iran (Lotfalipour et al., 2010). Concerning multiple countries, there are studies on ASEAN (Behera and Dash, 2017; Saboori and Sulaiman, 2013; Nasir et al, 2019); on emerging countries in OECD (Mamun et al., 2014; Saboori et al., 2014; Belke et al., 2011; Al-mulali et al., 2012); in Africa (Adom et al., 2012); on the GCC economies (Salahuddin and Gow, 2014; Salahuddin et al., 2015), on a larger sample of lower, middle and high-income and OECD and non-OECD countries (Mamun et al., 2014); on the BRICS (Apergis and Payne, 2011) 
and on European Countries (Pham et al, 2020). Despite the great volume of work which has been conducted exploring the nexus between energy consumption, growth of economy (GDP, income) and $\mathrm{CO}_{2}$ emissions, there seems to be no unanimous consensus while provides the rationale to the subject study on Australia.

There is a strong emphasis in the literature that solely focusing on the growth of the economy as a determinant of emissions is not a cogent strategy to comprehend the causes of environmental degradation. For instance, Lantz and Feng (2006) argued that the EKC can be influenced by technological as well as population. In this regard, York et al (2003) argued that the STIRPAT framework is more suitable to investigate the effects of determinants of $\mathrm{CO} 2$ emissions. However, the studies that used STIRPAT to investigate the effect of the population reported the impact of different magnitude (Wei, 2011). Similarly, while employing the STIRPAT framework, Poumanyvong and Kaneko (2010) reported that the effect of urbanisation on emissions varies among, low, middle- and high-income countries. Shi (2003) reported that the impact of population on emissions is more pronounced in developing than developed economies. However, MartínezZarzosofact and Maruotti (2011) reported that the results varied even among a single income group of developing countries. These contrasting results provide the rationale to our strategy of using both EKC and STIRPAT framework and taking an inclusive approach to the determinants of environmental degradation while specifically focusing on Australia.

\subsection{Financial development, Trade and environment nexus}

Financial development is a board phenomenon which entails increase in foreign direct investment (FDI), capital account liberalisation and trade openness, enhanced banking services, expansion of the stock market. It is also a channel of economic development that can also have ecological consequences (Frankel and Romer, 1999). Stated differently, international financial activities enhance technological progress and proficiency and through connection with domestic firms, enhances economic activities (Alfaro et al., 2009). Therefore, financial development is crucial for innovation ( Tadesse, 2005; King and Levine, 1993) and such advanced technologies might contribute to emission reduction (Kumbarog lu et al., 2008). 
Nexus between various aspects of financial development and environment has gain attention in recent years. Some studies report an inverse relationship between FDI and energy intensity (Mielnik and Goldemberg, 2002). A financial sector that functions effectively can be associated with a decrease in $\mathrm{CO}_{2}$ (Tamazian et al., 2009) since financial development enhances opportunities for the environmental project at a lower financing cost. There is also empirical evidence on the banking sector, focusing on bank deposits to GDP and financial system deposits to GDP, that suggest a positive impact on energy consumption in the economies of Central and Eastern Europe (Sadorsky, 2011). There is also empirical research which explored how capital inflows might impact the environment. In one of the pioneering study, Tamazian et al., (2009) asserted that financial development enhances the environment by reducing emissions in BRICS countries. Supporting this view, Jalil and Feridun (2011) explored the effect of financial development, economic growth, and energy usage on environmental degradation in China and conclude that financial development decreases air pollution which supports EKC hypothesis. Later, Shahbaz et al. (2013) reported a reduction in South African emission due to financial development, while Dogan and Seker (2016) found that financial development lowers $\mathrm{CO}_{2}$ emission in countries that are ranked at the top in the renewable energy attractiveness index. However, there are other researchers which have argued that as a financial sector develops, it is likely to encourage customers to rely more on energy, which ultimately results in a greater level of greenhouse gas emissions (Zhang, 2011; Al-mulali et al., 2012); Shahbaz et al 2016a; Shahbaz et al., 2016b; Javid and Sharif, 2016; Salahuddin et al., 2018).

In addition to the positive or negative impact of financial development on the environment, some studies suggest a neutral effect. The neutral results show no significant correlation between financial development. For example, Ozturk and Acaravci (2013) used credit to the private sector as a measure of financial development and indicated the absence of any relationship with carbon dioxide emissions in Turkey. Furthermore, exploring data from multiple countries and different regions, Omri et al. (2015), Charfeddine and Ben (2016), and Bekhet et al. (2017) reported the neutral impact of financial development on environmental degradation in selected MENA, UAE, and GCC countries, respectively. Addition to this, using the bank index as a measure of financial development, Çoban and Topcu (2013) provide evidence of a neural association between 
the development of the financial sector and $\mathrm{CO}_{2}$ emissions in $27 \mathrm{EU}$ economies. It is vital to consider the role of the financial sector in environmental degradation as climate change can also adversely affect financial stability (Dafermos et al., 2018).

Trade openness is also a vital factor which could influence the environment through technique and composition effects (Antweiler et a., 2001). The first group of scholars argue that trade openness enhances more opportunities for a country to access global markets, but it opens more competition which forces the country to increase the efficiency of utilizing scare resources and importing technologies to mitigate carbon emissions (Helpman, 1998). Therefore, trade openness is fruitful for the environment due to the technique effect (Shahbaz et al., 2012; Grether et al., 2007; Ferrantino, 1997). The second group of scholars oppose this argument suggesting that the international trade leads to depletion of natural resources and deterioration of environment (Copeland and Taylor, 2001; Schmalensee et al., 1998). Hence, the overarching evidence on the relationship between trade openness and the environment is also contrasting. To reiterate, the findings on the effect of financial development and environment are also inconclusive. Most likely this could be due to the reason that the scholars have used various methodologies and different proxies to measure financial development and other pollutants. As Ang (2009) asserted, usage of different proxies could have implications for the empirical findings. Further, many studies on this subject have employed panel data as well as time-series data to examine how financial development affect $\mathrm{CO}_{2}$ emissions at multi-country and single country levels. The panel datasets consist of five Asian (Chandran and Foon, 2013; Behera and Dash, 2017; Zhu et al., 2016; Baek, 2016;) Africa ( Kivyiro and Arminen, 2014; Bokpin, 2017); Middle East (Al-mulali et al., 2012) and BRICS (Pao and Tsai, 2011). Similarly, there are studies which have focused on a singlecountry and employed time-series data (Zhang, 2011; Lau et al., 2014; Seker et al., 2015; Sbia et al., 2014); or panel data (Ren et al., 2014; Peng et al., 2016; Zhang and Zhou, 2016). The literature shows various methodologies, although the subject paper follows Poumanyvong and Kaneko (2010), Shahbaz et al.,(2015), Shahbaz et al., (2016), Sheng and Guo (2016), Lin et al (2017) and Pham et al (2020) as they used the STIRPAT model by Dietz and Rosa (1997) to explore the determinants of $\mathrm{CO}_{2}$ emissions. The STIRPAT model was extended from IPAT model developed initially by (Ehrlich and Holdren, 1971), in which a stochastic version of the Impact $=$ Population*Affluence*Technology (IPAT) 
model to estimate the effects of population, affluence, and technology on national $\mathrm{CO}_{2}$ emissions. Several empirical studies explore the issues regarding $\mathrm{CO}_{2}$ emissions in many single and multiple countries. The lack of a comprehensive study on environmental degradation in Australia calls for more research to fill this gap and give us an understanding of factors driving the Australian environment degradation. Furthermore, most of the previous empirical research has used a single proxy of financial development while this paper measures financial development as different proxies (overall financial development, financial institution efficiency, financial market access, financial market development, financial market efficiency) with three dimensions (financial depth, financial efficiency and financial access). Nonetheless, we have also included a comprehensive set of explanatory factors that includes energy consumption, industrialisation and trade openness gain a deeper insight into the factors that leads to environmental degradation.

\section{Methodology and data}

This study investigates the factors driving Australian environmental degradation and in this endeavour, it is based on two most important theoretical frameworks in environmental economics, the EKC and the STIRPAT based on the seminal work by Dietz and Rosa (1997), as our baseline model. The EKC is developed from the Kuznets curve of Kuznets (1955), which states a non-linear association between economic development and inequality of income, to explain the dynamics between economic development and degradation of the environment. Specifically, the non-linear relationship follows the inverted-U shape. Empirically, investigation of the EKC is carried out by using income level and it's squared value and $\mathrm{CO}_{2}$ emissions to depict degradation of the environment (e.g. see Pata (2018)).

The STIRPAT model is likely more detailed in investigating the causes of environmental degradation by defining three main factors, i.e. population, economic development (or affluence), and technology (or the efficiency in economic production and energy consumption). Both the EKC and STIRPAT model are widely employed (e.g., Shahbaz et al., (2018), Phuc Nguyen et al., (2020), Pham et al (2020)). The STIRPAT is developed from the Influence, Population, Affluence, and Technology (IPAT) framework based on the seminal work by Ehrlich and Holdren (1971). The IPAT model relates the impacts of the population (P), affluence (A) and technology (T) on the environment (I) as follows: 


$$
I=P A T \quad[1]
$$

Dietz and Rosa (1997) modified this version to a stochastic version to tackle reformulations of IPAT model in empirical investigations as follow:

$$
I_{t}=\alpha_{t} P_{t}^{\pi_{1}} A_{t}^{\pi_{2}} T_{t}^{\pi_{3}} \varepsilon_{i t}
$$

where $t$ denotes time $t$. $\alpha$ characterizes the country-specific effect, $\pi$ is the elasticity of environmental impacts of right-hand factors (P, A, T). The model [2] is taken in logarithms for testing as follow:

$$
\ln I_{t}=\alpha_{t}+\pi_{1} \ln P_{t}+\pi_{2} \ln A_{t}+\pi_{3} \ln T_{t}+\varepsilon^{\prime}{ }_{i t}
$$

To adjust for the population size, the model [3] can be transformed into per capita forms for all variables by dividing both sides by total populations. That is, the empirical estimations for the case of Australia can be formed as follow:

$$
\mathrm{CO2}_{t}=\beta_{0}+\beta_{1} \text { Income }_{t}+\beta_{2} \text { Energy }_{t}+v_{i t}
$$

In which: $\mathrm{CO}_{2}$ is per capita emissions of $\mathrm{CO}_{2}$ which represents for degradation of the environment by the notion that higher $\mathrm{CO}_{2}$ emissions mean lower environmental quality; Income is real GDP per capita, which represents for economic development (or affluence); Energy is energy consumption per capita, which represents for energy consumption (or technology) with the notion that a higher energy consumption per capita means lower efficiency of energy usage or lower technological development. All these variables are taking in logarithms forms as in model [3]. To incorporate the framework of the EKC in empirical investigation, the square term of income level is added as done in many previous studies (Javid \& Sharif, 2016; Katircioğlu \& Taşpinar, 2017; Pata, 2018; Nasir et al 2019). The empirical estimations would be:

$$
\mathrm{CO}_{t}=\beta_{0}+\beta_{1} \text { Income }_{t}+\beta_{1}^{\prime} \text { Income }^{\wedge} 2_{t}+\beta_{2} \text { Energy }_{t}+v_{i t}^{\prime}
$$

Besides that, there are other important drivers of $\mathrm{CO}_{2}$ emissions, namely trade openness (Hanif, 2018; Pham et al., 2020), industrialization (Jiang and Lin, 2012; Shahbaz and Lean, 2012), and financial development (Adams and Klobodu, 2018; Shahbaz et al., 2018). Therefore, these factors are added as augmented drivers of $\mathrm{CO} 2$ emissions as follow: 


$$
\begin{gathered}
\operatorname{CO2}_{t}=\beta_{0}+\beta_{1} \text { Income }_{t}+\beta^{\prime}{ }_{1} \text { Income }^{\wedge} 2_{t}+\beta_{2} \text { Energy }_{t}+\beta_{3} \text { Industry }_{t}+\beta_{4} \text { Trade }_{t} \\
+\beta_{5} \text { FD }_{t}+v^{\prime \prime}{ }_{i t}
\end{gathered}
$$

in which: Industry is the industrial value-added per capita, which represents for industrialization; Trade is total trade value per capita, which represents for trade openness; and FD is financial development, which will be measured in different forms and will be explained later in this section. Both industrialization and trade openness are calculated in log forms as well.

In term of data, the study collects data from two main sources. First, the data of $\mathrm{CO} 2$ emissions, real GDP per capita, trade openness and industrialization are collected from the World Development Indicators of World Bank (WDIs). The Department of the Environment and Energy publishes regular Quarterly Updates on Australia's greenhouse gas emissions. Concerning economic variables, the real GDP per capita is a measurement of the total Australian economic output divided by its population and the figures are adjusted for inflation. The Australian economy is dominated by its service sector, comprising $62.7 \%$ of the GDP and employing $78.8 \%$ of the labour force in 2014 . One of the highest value of services in Australia comes from the mining sector which accounted for $8.4 \%$ at around 2009-2010. Although trade in Australia is less than in other countries, or in other words, Australia's trade openness ratio is below the average for developed countries. The main reason is that Australia may produce many goods internally and does not need to trade for them externally. However, Australia's geographic location creates strong trade links with China and India, two of which are currently fast developing countries in the BRICS. Overall, these economic variables are collected in total values and then divided by the total population (which is also collected from WDIs as well) to obtain the per capita values. We have also transformed the data by taking natural logarithms.

In term of financial development, the study takes the liberty to make another contribution by examining different dimensions of financial development on emissions of $\mathrm{CO} 2$ in Australia. Therefore, we collected new proxies for financial development from financial development database of IMF. As argued by Svirydzenka (2016), the traditional proxies of FD such as domestic credit or stock market capitalization cannot capture all dimensions and sectors in the financial system. Furthermore, there are two main pillars of financial systems, financial 
institutions (i.e. venture capital firms, funds, insurance companies, banks and other non-bank financial institutions) and financial markets (i.e. bond markets, stock markets, money markets (wholesale) and by-passing traditional bank lending); they play a different role in economy which may have different impacts on $\mathrm{CO} 2$ emissions. Svirydzenka (2016) has constructed a new database of FD including nine indicators with three dimensions (financial access, financial depth, and financial efficiency) of each sub-sector (financial markets and financial institutions) and overall FD, which is freely provided by IMF. This database provides a very comprehensive database of financial development for empirical studies (Canh and Thanh 2020, Canh and Thong 2020). Therefore, we used this database for financial development. In Australia, financial services are the largest sector contributing to GDP, averaged around \$140 billion in 2016 (Treasury, 2020), it has been the main driver of economic growth. Consequently, Australia was rated as the best performing financial markets regarding its strength in financial stability and financial intermediation. The burgeoning development in the financial sector in Australia is worth to study if this development can push up or hinder the level of $\mathrm{CO} 2$ emissions.

Since the database from Svirydzenka (2016) is calculated in the form of indices, we do not transform them in the form of per capita. However, it does not influence the meaning of per capita since the index represents the development of financial systems. All financial proxies are transformed by taking natural logarithms. Furthermore, we collected five traditional proxies of FD for robustness check. They are the domestic credit by financial sector per capita (FD1), the domestic credit to private sector per capita (FD2), the domestic credit to the private sector by banks (FD3), capitalisation of domestic listed firms per capita (FD4), and the stocks traded value per capita (FD5). In fact, FD1, FD2, FD3 are likely proxies of credit supply from financial institutions, while FD4 and FD5 represent the development of financial markets (i.e. stock market). 
Table 1. Variables Details and Descriptive Analysis

\begin{tabular}{|c|c|c|c|c|c|c|c|c|c|}
\hline Variables & Definitions & Calculations & Sources & Availability & Obs & Mean & S.D. & Min & Max \\
\hline$\overline{\mathrm{CO} 2}$ & CO2 emissions & Log of CO2 emissions (metric tons per capita) & WDIs & $1960-2014$ & 35 & 2.792 & 0.063 & 2.684 & 2.901 \\
\hline Energy & Energy intensity & Log of Energy use (kg of oil equivalent per capita) & WDIs & $1960-2015$ & 35 & 8.565 & 0.083 & 8.424 & 8.694 \\
\hline Income & Economic development & Log of GDP per capita & WDIs & $1960-2018$ & 35 & 10.612 & 0.203 & 10.304 & 10.909 \\
\hline Industry & Industrialization & Log of Industry (including construction) value added per capita & WDIs & $1975-2018$ & 35 & 9.295 & 0.151 & 9.046 & 9.541 \\
\hline Trade & Trade openness & Log of Total trade value per capita & WDIs & $1960-2018$ & 35 & 13.653 & 0.683 & 12.706 & 14.894 \\
\hline OFD & $\begin{array}{l}\text { Overall financial } \\
\text { development }\end{array}$ & Log of overall financial development index & FD-IMF & $1980-2017$ & 35 & -0.441 & 0.345 & -1.094 & -0.049 \\
\hline FI & $\begin{array}{l}\text { Financial institutions' } \\
\text { development }\end{array}$ & Log of financial institutions index & FD-IMF & $1980-2017$ & 35 & -0.263 & 0.207 & -0.639 & -0.045 \\
\hline FID & $\begin{array}{l}\text { Financial institutions } \\
\text { depth }\end{array}$ & Log of Financial institutions depth index & FD-IMF & $1980-2017$ & 35 & -0.336 & 0.347 & -1.072 & -0.029 \\
\hline FIA & $\begin{array}{l}\text { Financial institutions } \\
\text { access }\end{array}$ & Log of Financial institutions access index & FD-IMF & $1980-2017$ & 35 & -0.367 & 0.223 & -0.761 & -0.149 \\
\hline FIE & $\begin{array}{l}\text { Financial institutions } \\
\text { efficiency }\end{array}$ & Log of Financial institutions efficiency index & FD-IMF & $1980-2017$ & 35 & -0.320 & 0.106 & -0.585 & -0.155 \\
\hline FM & $\begin{array}{l}\text { Financial markets' } \\
\text { development }\end{array}$ & Log of financial markets index & FD-IMF & $1980-2017$ & 35 & -0.729 & 0.598 & -2.004 & -0.075 \\
\hline FMD & Financial markets depth & Log of Financial markets depth index & FD-IMF & 1980-2017 & 35 & -0.732 & 0.667 & -2.079 & -0.024 \\
\hline FMA & Financial markets access & Log of Financial markets access index & FD-IMF & 1980-2017 & 35 & -0.694 & 0.561 & -1.900 & -0.128 \\
\hline FME & $\begin{array}{l}\text { Financial markets } \\
\text { efficiency }\end{array}$ & Log of Financial markets efficiency index & FD-IMF & $1980-2017$ & 35 & -0.811 & 0.618 & -2.435 & 0.000 \\
\hline
\end{tabular}

Notes: WDIs is World Bank's data base Development Indicators (Dec/2019 version, see http://datatopics.worldbank.org/world-development-indicators/); FD-IMF is the IMF's

financial development database (version 2019, see https://data.imf.org/?sk=F8032E80-B36C-43B1-AC26-493C5B1CD33B).

Table 2. Unconditional correlations

\begin{tabular}{|c|c|c|c|c|c|c|c|c|c|c|c|c|c|c|c|}
\hline \multicolumn{2}{|c|}{ Correlation } & $\mathrm{CO2}$ & Energy & Income & Industry & Trade & OFD & FI & FID & FIA & FIE & FM & FMD & FMA & FME \\
\hline \multicolumn{2}{|l|}{$\mathrm{CO2}$} & 1.00 & & & & & & & & & & & & & \\
\hline Energy & & $\begin{array}{l}0.92 * * * \\
0.00\end{array}$ & 1.00 & & & & & & & & & & & & \\
\hline \multirow{2}{*}{ Income } & & $0.81^{* * *}$ & $0.92^{* * *}$ & 1.00 & & & & & & & & & & & \\
\hline & $p$-value & 0.00 & 0.00 & & & & & & & & & & & & \\
\hline \multirow[t]{2}{*}{ Industry } & & $0.79 * * *$ & $0.90^{* * *}$ & $0.99 * * *$ & 1.00 & & & & & & & & & & \\
\hline & $p$-value & 0.00 & 0.00 & 0.00 & & & & & & & & & & & \\
\hline \multirow[t]{2}{*}{ Trade } & & $0.72^{* * *}$ & $0.86^{* * *}$ & $0.97^{* * *}$ & $0.97 * * *$ & 1.00 & & & & & & & & & \\
\hline & $p$-value & 0.00 & 0.00 & 0.00 & 0.00 & & & & & & & & & & \\
\hline \multirow[t]{2}{*}{ OFD } & & $0.84^{* * *}$ & $0.92^{* * *}$ & $0.96^{* * *}$ & $0.93^{* * *}$ & $0.87^{* * *}$ & 1.00 & & & & & & & & \\
\hline & $p$-value & 0.00 & 0.00 & 0.00 & 0.00 & 0.00 & & & & & & & & & \\
\hline FI & & $0.83^{* * *}$ & $0.94^{* * *}$ & $0.96^{* * *}$ & $0.94^{* * *}$ & $0.89^{* * *}$ & $0.99 * * *$ & 1.00 & & & & & & & \\
\hline
\end{tabular}




\begin{tabular}{|c|c|c|c|c|c|c|c|c|c|c|c|c|c|c|c|}
\hline \multirow{3}{*}{ FID } & $p$-value & 0.00 & 0.00 & 0.00 & 0.00 & 0.00 & 0.00 & & & & & & & & \\
\hline & & $0.75^{* * *}$ & $0.89^{* * *}$ & $0.88^{* * *}$ & $0.85 * * *$ & $0.81^{* * *}$ & $0.94^{* * *}$ & $0.97^{* * *}$ & 1.00 & & & & & & \\
\hline & $p$-value & 0.00 & 0.00 & 0.00 & 0.00 & 0.00 & 0.00 & 0.00 & & & & & & & \\
\hline \multirow{2}{*}{ FIA } & & $0.85^{* * *}$ & $0.95^{* * *}$ & $0.95^{* * *}$ & $0.92 * * *$ & $0.86^{* * *}$ & $0.99^{* * *}$ & $1.00^{* * *}$ & $0.95^{* * *}$ & 1.00 & & & & & \\
\hline & $p$-value & 0.00 & 0.00 & 0.00 & 0.00 & 0.00 & 0.00 & 0.00 & 0.00 & & & & & & \\
\hline \multirow{2}{*}{ FIE } & & $0.57^{* * *}$ & $0.57^{* * *}$ & $0.72^{* * *}$ & $0.73^{* * *}$ & $0.74^{* * *}$ & $0.60^{* * *}$ & $0.57^{* * *}$ & $0.35^{* *}$ & $0.57^{* * *}$ & 1.00 & & & & \\
\hline & $p$-value & 0.00 & 0.00 & 0.00 & 0.00 & 0.00 & 0.00 & 0.00 & 0.04 & 0.00 & & & & & \\
\hline \multirow[t]{2}{*}{ FM } & & $0.82^{* * *}$ & $0.88^{* * *}$ & $0.93^{* * *}$ & $0.90^{* * *}$ & $0.84^{* * *}$ & $0.99 * * *$ & $0.97 * * *$ & $0.93^{* * *}$ & $0.97^{* * *}$ & $0.58^{* * *}$ & 1.00 & & & \\
\hline & $p$-value & 0.00 & 0.00 & 0.00 & 0.00 & 0.00 & 0.00 & 0.00 & 0.00 & 0.00 & 0.00 & & & & \\
\hline \multirow[t]{2}{*}{ FMD } & & $0.82^{* * *}$ & $0.89 * * *$ & $0.93^{* * *}$ & $0.90^{* * *}$ & $0.83^{* * *}$ & $0.98^{* * *}$ & $0.96^{* * *}$ & $0.91^{* * *}$ & $0.97^{* * *}$ & $0.60^{* * *}$ & $0.98^{* * *}$ & 1.00 & & \\
\hline & $p$-value & 0.00 & 0.00 & 0.00 & 0.00 & 0.00 & 0.00 & 0.00 & 0.00 & 0.00 & 0.00 & 0.00 & & & \\
\hline \multirow[t]{2}{*}{ FMA } & & $0.76^{* * *}$ & $0.81^{* * *}$ & $0.89 * * *$ & $0.85 * * *$ & $0.78^{* * *}$ & $0.96^{* * *}$ & $0.93^{* * *}$ & $0.89 * * *$ & $0.94^{* * *}$ & $0.57^{* * *}$ & $0.98^{* * *}$ & $0.96^{* * *}$ & 1.00 & \\
\hline & $p$-value & 0.00 & 0.00 & 0.00 & 0.00 & 0.00 & 0.00 & 0.00 & 0.00 & 0.00 & 0.00 & 0.00 & 0.00 & & \\
\hline \multirow[t]{2}{*}{ FME } & & $0.83^{* * *}$ & $0.89 * * *$ & $0.90^{* * *}$ & $0.87 * * *$ & $0.83^{* * *}$ & $0.96^{* * *}$ & $0.94^{* * *}$ & $0.93^{* * *}$ & $0.94^{* * *}$ & $0.49^{* * *}$ & $0.96^{* * *}$ & $0.91^{* * *}$ & $0.91^{* * *}$ & 1.00 \\
\hline & $p$-value & 0.00 & 0.00 & 0.00 & 0.00 & 0.00 & 0.00 & 0.00 & 0.00 & 0.00 & 0.00 & 0.00 & 0.00 & 0.00 & \\
\hline
\end{tabular}

Notes: ${ }^{* *},{ }^{* * *}$ are significant levels at $5 \%$ and $1 \%$, respectively; All variables are in logarithms forms. 


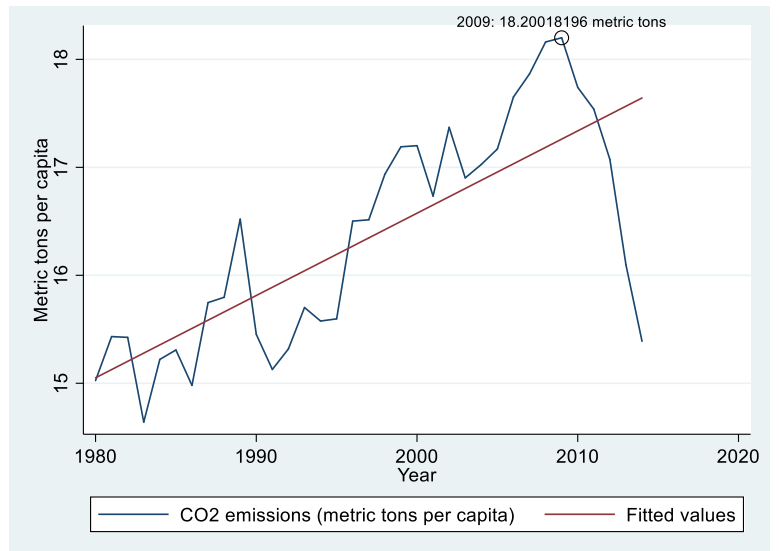

1a) CO2 emissions per capita

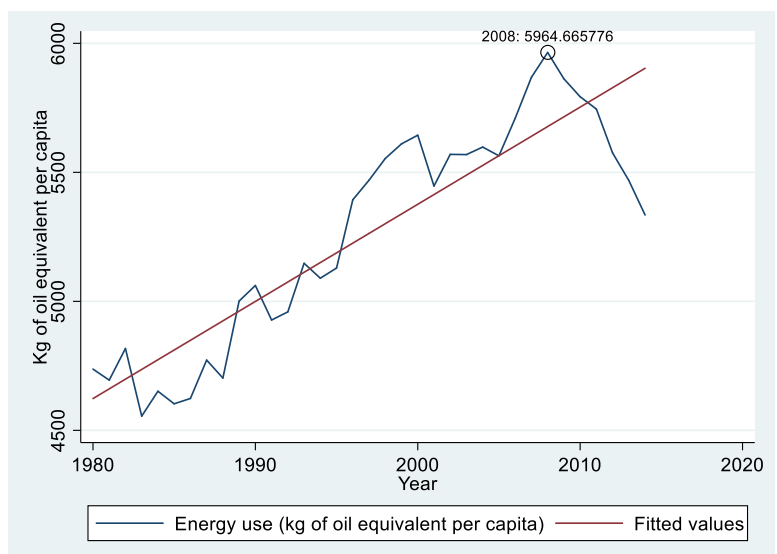

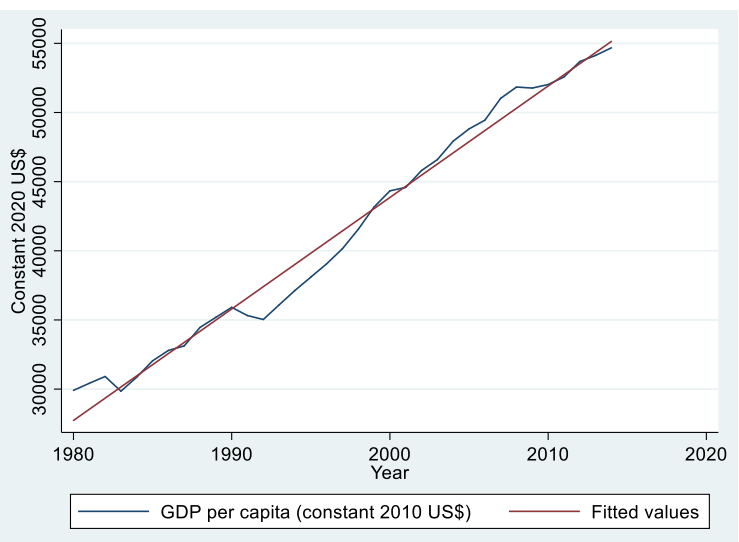

1b) GDP per capita

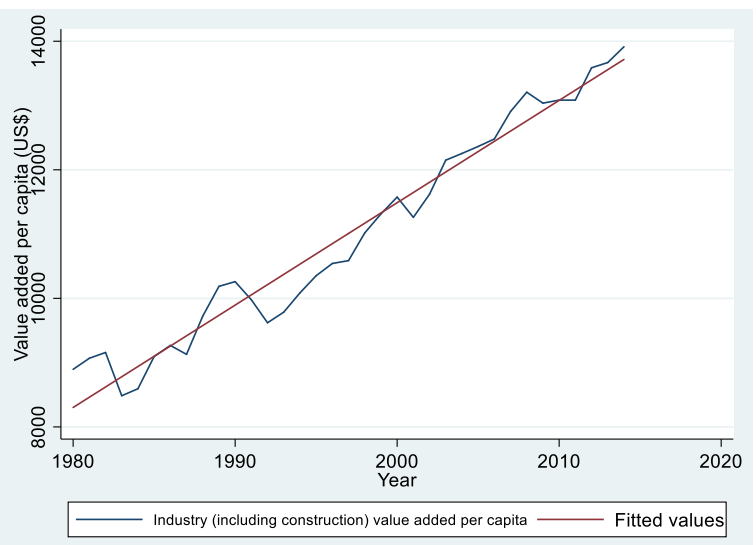

1d) Industry value added per capita

1c) Energy use per capita

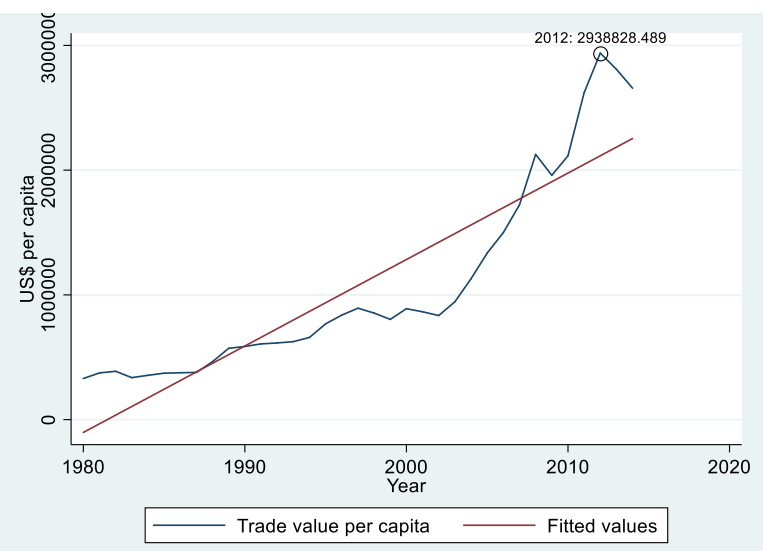

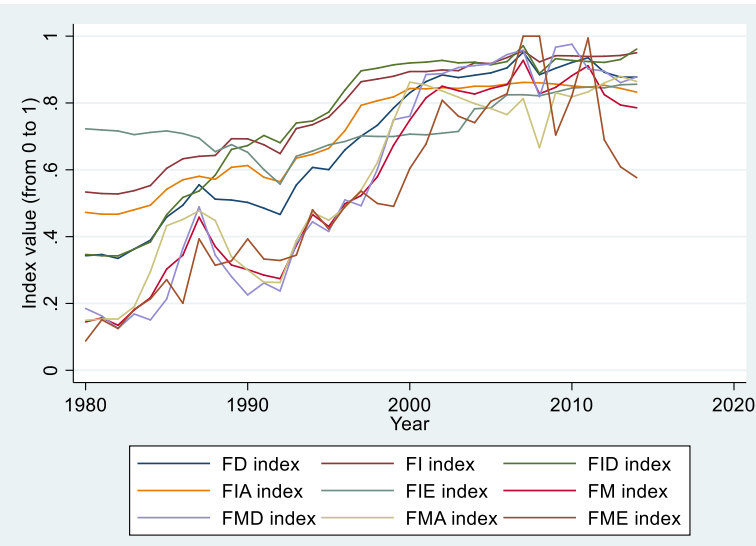

1g) Financial development indices

1e) Trade value per capita

Figure 1. CO2 emissions and Economic factors in Australia over the period 1980-2014

Table 1 entails details on the definition of variables, calculations, sources of data, time availability, and data description. In our dataset, the data of $\mathrm{CO} 2$ emissions is available to 
2014, while the data of financial development from IMF is available from 1980 thus the period of 1980-2014 is chosen for empirical analysis as best period. Table 2 presents the unconditional correlation matrix for all variables. It is important to notice high positive correlations among variables. Table 2 shows that there may be the issue of multicollinearity between variables as high correlations. That suggests us to do further tests, especially cointegration tests for our model. It can be observed in Figure 1 that most variables have the same increasing trends over the period 1980-2014. This hints an important notice for empirical analysis about the cointegration among variables. 
Table 3. Stationary tests

\begin{tabular}{|c|c|c|c|c|c|c|c|c|c|}
\hline \multirow[t]{2}{*}{ Variables } & \multicolumn{5}{|c|}{ Stationary tests for level } & \multicolumn{4}{|c|}{ Stationary tests for $1^{\text {st }}$ difference } \\
\hline & & $\begin{array}{l}\text { Dickey-Fuller test - } \\
\text { Test statistic - Z(t) }\end{array}$ & $\begin{array}{l}\text { DF-GLS test - } \\
\text { DF-GLS tau Test } \\
\text { Statistic at lag } 1\end{array}$ & $\begin{array}{l}\text { Phillips-Perron test } \\
\text { Test statistic - Z(rho) }\end{array}$ & $\begin{array}{l}\text { KPSS test Test- } \\
\text { statistic for lag } 0\end{array}$ & $\begin{array}{l}\text { Dickey-Fuller test - } \\
\text { Test statistic - Z(t) }\end{array}$ & $\begin{array}{l}\text { DF-GLS test - } \\
\text { DF-GLS tau Test } \\
\text { Statistic at lag } 1\end{array}$ & $\begin{array}{l}\text { Phillips-Perron test } \\
\text { Test statistic - } \\
\text { Z(rho) }\end{array}$ & $\begin{array}{l}\text { KPSS test-Test statistic } \\
\text { for lag } 0\end{array}$ \\
\hline \multirow[t]{2}{*}{$\mathrm{CO2}$} & No trend & -1.585 & -1.255 & -4.994 & $2.35^{* * *}$ & $-5.537^{* * *}$ & -2.871 & $-35.69^{* * *}$ & .273 \\
\hline & With trend & -0.677 & & -5.279 & $0.235^{* * *}$ & $-5.714^{* * *}$ & & $-36.56^{* * *}$ & .122 \\
\hline \multirow{2}{*}{ Energy } & No trend & -1.293 & -0.934 & -2.302 & $3.08^{* * *}$ & $-6.100^{* * *}$ & $-3.640^{* *}$ & $-39.45^{* * *}$ & .231 \\
\hline & With trend & -0.819 & & -4.889 & $0.392^{* * *}$ & $-6.295^{* * *}$ & & $-39.30^{* * *}$ & .126 \\
\hline \multirow[t]{2}{*}{ Income } & No trend & -0.379 & -1.862 & -0.183 & $3.52^{* * *}$ & $-4.838^{* * *}$ & -3.349 & $-25.61^{* * *}$ & .116 \\
\hline & With trend & -1.857 & & -8.945 & $0.267^{* * *}$ & $-4.763^{* * *}$ & & $-25.48^{* * *}$ & .113 \\
\hline \multirow[t]{2}{*}{ Industry } & No trend & -0.115 & -3.257 & 0.097 & $3.43^{* * *}$ & $-5.124 * * *$ & $-4.629 * * *$ & $-23.28^{* * *}$ & .058 \\
\hline & With trend & -3.321 & & -13.93 & 0.144 & $-5.086^{* * *}$ & & $-23.55^{* * *}$ & .038 \\
\hline \multirow[t]{2}{*}{ Trade } & No trend & 0.173 & -2.029 & 0.130 & $3.34^{* * *}$ & $-4.286^{* * *}$ & $-3.562^{* *}$ & $-22.84^{* * *}$ & .113 \\
\hline & With trend & -2.026 & & -8.138 & $0.396^{* * *}$ & $-4.289^{* *}$ & & $-23.05^{* *}$ & .059 \\
\hline \multirow[t]{2}{*}{ OFD } & No trend & -1.871 & -0.861 & -1.927 & $3.25^{* * *}$ & $-4.549 * * *$ & $-3.702^{* *}$ & $-27.06^{* * *}$ & .351 \\
\hline & With trend & -0.791 & & -3.681 & $0.487^{* * *}$ & $-4.912^{* * *}$ & & $-27.49 * * *$ & .075 \\
\hline \multirow[t]{2}{*}{ FI } & No trend & -1.666 & -0.901 & -1.451 & $3.28^{* * *}$ & $-5.222 * * *$ & $-3.783^{* * *}$ & $-29.08^{* * *}$ & .305 \\
\hline & With trend & -0.860 & & -2.329 & $0.664^{* * *}$ & $-5.641^{* * *}$ & & $-27.86^{* * *}$ & .062 \\
\hline \multirow{2}{*}{ FID } & No trend & -2.895 & -0.518 & -2.300 & $2.88^{* * *}$ & $-4.347^{* * *}$ & $-3.508^{* *}$ & $-27.24^{* * *}$ & $.855^{* * *}$ \\
\hline & With trend & -0.811 & & -1.451 & $0.816^{* * *}$ & $-5.608^{* * *}$ & & $-29.04^{* * *}$ & .074 \\
\hline \multirow[t]{2}{*}{ FIA } & No trend & -1.757 & -0.968 & -1.728 & $3.23^{* * *}$ & $-4.281^{* * *}$ & $-3.861^{* * *}$ & $-22.97 * * *$ & .403 \\
\hline & With trend & -0.418 & & -1.689 & $0.603^{* * *}$ & $-4.712^{* * *}$ & & $-23.04 * *$ & .102 \\
\hline \multirow[t]{2}{*}{ FIE } & No trend & -0.493 & -1.282 & -1.241 & $2.15^{* * *}$ & $-5.355^{* * *}$ & $-3.792 * * *$ & $-30.16^{* * *}$ & .252 \\
\hline & With trend & -1.871 & & -5.163 & $0.648^{* * *}$ & $-5.514^{* * *}$ & & $-30.47^{* * *}$ & .066 \\
\hline \multirow{2}{*}{ FM } & No trend & -2.072 & -0.918 & -2.800 & $3.07^{* * *}$ & $-4.583^{* * *}$ & $-3.912^{* * *}$ & $-27.50^{* * *}$ & .306 \\
\hline & With trend & -1.355 & & -6.175 & $0.393^{* * *}$ & $-4.845^{* * *}$ & & $-28.23^{* * *}$ & .057 \\
\hline \multirow[t]{2}{*}{ FMD } & No trend & -1.238 & -1.163 & -2.211 & $3.08^{* * *}$ & $-5.106 * * *$ & $-3.682^{* *}$ & $-27.68^{* * *}$ & .093 \\
\hline & With trend & -1.928 & & -10.80 & $0.312^{* * *}$ & $-5.121^{* * *}$ & & $-26.99 * * *$ & .057 \\
\hline \multirow{2}{*}{ FMA } & No trend & -2.079 & -1.639 & -3.824 & $2.77^{* * *}$ & $-3.556^{* *}$ & $-3.709^{* *}$ & $-19.61^{* * *}$ & .231 \\
\hline & With trend & -1.857 & & -8.840 & $0.280^{* * *}$ & $-3.682^{* *}$ & & $-20.49^{* *}$ & .071 \\
\hline \multirow{2}{*}{ FME } & No trend & -2.949 & -0.719 & -4.844 & $2.92^{* * *}$ & $-9.036^{* * *}$ & $-4.419 * * *$ & $-44.88^{* * *}$ & .317 \\
\hline & With trend & -2.848 & & -11.49 & $0.430^{* * *}$ & $-10.02^{* * *}$ & & $-44.67^{* * *}$ & .029 \\
\hline
\end{tabular}

$\&-3.568$ for tests with 1st difference of variables) for significant levels of $1 \%$ and $5 \%$, respectively; The critical values of DF-GLS test no trend are -3.770 and -3.386 (and - 3.770 \& -3.400 for tests with 1st difference of variables) for significant levels of $1 \%$ and $5 \%$,

\&-3.568 for tests with 1st difference of variables) for significant levels of $1 \%$ and $5 \%$, respectively; The critical values of DF-GLS test no trend are -3.770 and -3.386 (and $-3.770 \&-3.400$ for tests with 1 st difference of variables) for significant levels of $1 \%$ and $5 \%$,
respectively; The critical values of Phillips-Perron test no trend are -17.812 and -12.788 (and $-17.744 \&-12.756$ for tests with 1st difference of variables) with significant levels of $1 \%$ and $5 \%$, respectively; The critical values of Phillips-Perron test with trend are - 23.652 and 18.584 (and - 23.524 \& -18.508 for tests with 1st difference of variables) with significant levels of $1 \%$ and $5 \%$, respectively; In KPSS test: the null hypothesis is stationarity; The critical values of KPSS test with no trend are 0.463 and 0.739 (and 0.463 \& 0.739 for tests with 1 s

difference of variables) with significant levels of $1 \%$ and $5 \%$, respectively; The critical values of KPSS test with trend are 0.146 and 0.216 (and $0.146 \& 0.216$ for tests with 1 st difference of variables) with significant levels of $1 \%$ and $5 \%$, respectively; ${ }^{* *}, * * *$ are significant

levels at $5 \%$ and $1 \%$, respectively; All variables are tested in logarithms forms. 
In term of econometric techniques, the study follows the standard robust procedures for time series by checking stationarity of each variable first. Four different stationary tests are employed including Dickey-Fuller (DF) test (Dickey and Fuller, 1979), the DF-GLS test (Elliot, et al., 1996), Phillips-Perron test (PP) test (Phillips and Perron, 1988), Kwiatkowski-Phillips-Schmidt-Shin test or KPSS test (Kwiatkowski et al., 1992). The tests are done for both level and $1^{\text {st }}$ difference of each variable. The results in Table 3 show insignificant statistics of DF, DF-GLS, and PP tests and statistical significance of the KPSS test, which imply the non-stationarity of all variables at levels. The tests for $1^{\text {st }}$ differences of variables show opposite results with statistical significance of DF, DF-GLS, and PP, and the insignificance of the KPSS test, which means the variables are stationary at $1^{\text {st }}$ differences.

In this case, all variables are found to be stationary at the first difference I(1), the study employs the Granger causality (Granger, 1969) for the $1^{\text {st }}$ differences of all variables to examine the causalities among variables. Moreover, the Johansen cointegration test (Johansen, 1991) is employed to examine the cointegration among variables in levels. Next section will present the results and the estimate.

\section{Empirical results}

\subsection{Granger causalities}

Results of Granger causality tests are presented in Tables 4 and 5. It shows that the income, industry and energy have a statistically significant causal association with $\mathrm{CO}_{2}$ emissions in most cases. Meanwhile, trade openness is found with no statistical significance. Interestingly, no indicator of FD has causality on $\mathrm{CO}_{2}$ emissions. The test for traditional proxies of FD shows that only FD4 (stock market capitalization) has statistically significant causality. That is, economic development, consumption of energy and industrialization are likely the core causes of $\mathrm{CO}_{2}$ emissions in Australia over the period of study. In return, $\mathrm{CO}_{2}$ emissions are documented with statistically significant causality on income, energy, industry as well. In term of financial development, $\mathrm{CO}_{2}$ emissions have no causality on all nine indicators from financial development database of IMF. The tests for traditional proxies of FD shows that CO2 emissions has causality on FD4 only. That is, there is two ways causal association between economic development, consumption of energy, industrialization, stock market capitalization and $\mathrm{CO}_{2}$ emissions. 
Table 4. Causality tests

\begin{tabular}{|c|c|c|c|c|c|c|c|c|c|c|c|}
\hline Model with & & OFD & & FI & & FID & & FIA & & FIE & \\
\hline Equation & Excluded & chi2 & Prob>chi2 & chi2 & Prob>chi2 & chi2 & Prob >chi2 & chi2 & Prob $>$ chi2 & chi2 & Prob>chi2 \\
\hline$\Delta \mathrm{CO} 2$ & $\Delta$ Income & $4.16^{* *}$ & 0.04 & $4.69^{* *}$ & 0.03 & $5.01^{* *}$ & 0.03 & $4.29 * *$ & 0.04 & $6.42^{* * *}$ & 0.01 \\
\hline$\Delta \mathrm{CO} 2$ & $\Delta$ Energy & $3.76^{* *}$ & 0.05 & 3.55 & 0.06 & $3.93^{* *}$ & 0.05 & 3.57 & 0.06 & $2.95^{* * *}$ & 0.09 \\
\hline$\triangle \mathrm{CO} 2$ & $\Delta$ Industry & $6.14^{* * *}$ & 0.01 & $6.64^{* * *}$ & 0.01 & $7.23^{* * *}$ & 0.01 & $6.40^{* * *}$ & 0.01 & $8.03^{* * *}$ & 0.01 \\
\hline$\Delta \mathrm{CO} 2$ & $\Delta$ Trade & 1.03 & 0.31 & 1.20 & 0.27 & 1.68 & 0.20 & 1.26 & 0.26 & 1.48 & 0.23 \\
\hline$\Delta \mathrm{CO} 2$ & $\Delta \mathrm{FD}$ & 0.00 & 0.98 & 0.00 & 0.99 & 0.56 & 0.45 & 0.01 & 0.92 & 1.65 & 0.20 \\
\hline$\Delta \mathrm{CO} 2$ & ALL & 10.30 & 0.07 & 10.30 & 0.07 & $11.04^{* *}$ & 0.05 & 10.32 & 0.07 & $12.46^{* *}$ & 0.03 \\
\hline$\Delta$ Income & $\Delta \mathrm{CO} 2$ & $7.19^{* * *}$ & 0.01 & $10.56^{* * *}$ & 0.00 & $9.20^{* * *}$ & 0.00 & $11.57^{* * *}$ & 0.00 & $10.11^{* * *}$ & 0.00 \\
\hline$\Delta$ Income & $\Delta$ Energy & $3.99 * *$ & 0.05 & $5.77^{* *}$ & 0.02 & $3.88^{* *}$ & 0.05 & $6.69^{* * *}$ & 0.01 & $4.52^{* *}$ & 0.03 \\
\hline$\Delta$ Income & $\Delta$ Industry & 0.27 & 0.60 & 1.23 & 0.27 & 1.75 & 0.19 & 0.68 & 0.41 & 0.76 & 0.38 \\
\hline$\Delta$ Income & $\Delta$ Trade & 0.24 & 0.63 & 0.04 & 0.85 & 0.07 & 0.80 & 0.03 & 0.87 & 0.46 & 0.50 \\
\hline$\Delta$ Income & $\Delta \mathrm{FD}$ & $5.63^{* *}$ & 0.02 & $4.08^{* *}$ & 0.04 & 1.53 & 0.22 & $5.21^{* *}$ & 0.02 & 1.63 & 0.20 \\
\hline$\Delta$ Income & ALL & $20.20^{* * *}$ & 0.00 & $18.06^{* * *}$ & 0.00 & $14.55^{* * *}$ & 0.01 & $19.62^{* * *}$ & 0.00 & $14.69 * * *$ & 0.01 \\
\hline$\Delta$ Energy & $\Delta \mathrm{CO} 2$ & $4.01^{* *}$ & 0.05 & $4.13^{* *}$ & 0.04 & $3.89^{* *}$ & 0.05 & $4.18^{* *}$ & 0.04 & $3.94 * *$ & 0.05 \\
\hline$\Delta$ Energy & $\Delta$ Income & 0.00 & 0.95 & 0.04 & 0.83 & 0.00 & 1.00 & 0.05 & 0.82 & 0.08 & 0.78 \\
\hline$\Delta$ Energy & $\Delta$ Industry & 0.01 & 0.93 & 0.03 & 0.85 & 0.02 & 0.88 & 0.06 & 0.80 & 0.00 & 0.96 \\
\hline$\Delta$ Energy & $\Delta$ Trade & 0.19 & 0.67 & 0.61 & 0.43 & 1.19 & 0.28 & 0.52 & 0.47 & 0.44 & 0.51 \\
\hline$\Delta$ Energy & $\Delta \mathrm{FD}$ & 0.05 & 0.82 & 0.81 & 0.37 & 3.26 & 0.07 & 0.42 & 0.52 & 1.24 & 0.27 \\
\hline$\Delta$ Energy & ALL & 5.06 & 0.41 & 5.94 & 0.31 & 8.75 & 0.12 & 5.48 & 0.36 & 6.43 & 0.27 \\
\hline$\Delta$ Industry & $\Delta \mathrm{CO} 2$ & $6.89^{* * *}$ & 0.01 & $8.63^{* * *}$ & 0.00 & $8.19^{* * *}$ & 0.00 & $8.70^{* *}$ & 0.00 & $8.66^{* * *}$ & 0.00 \\
\hline$\Delta$ Industry & $\Delta$ Income & 1.99 & 0.16 & 2.94 & 0.09 & $3.80^{* *}$ & 0.05 & 2.64 & 0.10 & 2.78 & 0.10 \\
\hline$\Delta$ Industry & $\Delta$ Energy & $5.42^{* *}$ & 0.02 & $6.19^{* * *}$ & 0.01 & $5.52^{* *}$ & 0.02 & $5.93^{* *}$ & 0.02 & $5.83^{* *}$ & 0.02 \\
\hline$\Delta$ Industry & $\Delta$ Trade & 0.08 & 0.78 & 0.00 & 0.98 & 0.00 & 0.98 & 0.01 & 0.94 & 0.07 & 0.79 \\
\hline$\Delta$ Industry & $\Delta \mathrm{FD}$ & 1.15 & 0.28 & 0.88 & 0.35 & 0.50 & 0.48 & 0.53 & 0.47 & 0.51 & 0.47 \\
\hline$\Delta$ Industry & ALL & $15.68^{* * *}$ & 0.01 & 15.29 & 0.01 & $14.76^{* * *}$ & 0.01 & $14.80^{* * *}$ & 0.01 & $14.77^{* * *}$ & 0.01 \\
\hline$\Delta$ Trade & $\Delta \mathrm{CO} 2$ & 0.45 & 0.50 & 1.00 & 0.32 & 0.93 & 0.33 & 0.92 & 0.34 & 1.05 & 0.31 \\
\hline$\Delta$ Trade & $\Delta$ Income & 0.16 & 0.69 & 0.02 & 0.88 & 0.03 & 0.86 & 0.22 & 0.64 & 0.00 & 0.98 \\
\hline$\Delta$ Trade & $\Delta$ Energy & 0.60 & 0.44 & 0.60 & 0.44 & 0.63 & 0.43 & 0.22 & 0.64 & 0.73 & 0.39 \\
\hline$\Delta$ Trade & $\Delta$ Industry & 0.06 & 0.81 & 0.03 & 0.87 & 0.06 & 0.80 & 0.10 & 0.75 & 0.00 & 0.95 \\
\hline$\Delta$ Trade & $\Delta \mathrm{FD}$ & 2.22 & 0.14 & 0.01 & 0.91 & 0.27 & 0.60 & 0.97 & 0.32 & 0.27 & 0.60 \\
\hline$\Delta$ Trade & ALL & 3.40 & 0.64 & 1.11 & 0.95 & 1.38 & 0.93 & 2.10 & 0.84 & 1.38 & 0.93 \\
\hline$\Delta \mathrm{FD}$ & $\Delta \mathrm{CO} 2$ & 0.31 & 0.58 & 3.28 & 0.07 & 0.76 & 0.38 & $6.16^{* * *}$ & 0.01 & 1.99 & 0.16 \\
\hline$\Delta \mathrm{FD}$ & $\Delta$ Income & 1.53 & 0.22 & 0.38 & 0.54 & 0.75 & 0.39 & 0.21 & 0.65 & 0.14 & 0.71 \\
\hline$\Delta \mathrm{FD}$ & $\Delta$ Energy & 0.04 & 0.85 & 1.21 & 0.27 & 0.34 & 0.56 & 1.77 & 0.18 & 2.15 & 0.14 \\
\hline$\Delta \mathrm{FD}$ & $\Delta$ Industry & 1.41 & 0.24 & 0.26 & 0.61 & 0.76 & 0.38 & 0.38 & 0.54 & 0.13 & 0.72 \\
\hline$\Delta \mathrm{FD}$ & $\Delta$ Trade & 2.04 & 0.15 & 0.02 & 0.88 & 0.05 & 0.82 & 0.07 & 0.80 & 0.12 & 0.73 \\
\hline$\Delta \mathrm{FD}$ & ALL & 4.80 & 0.44 & 4.17 & 0.53 & 1.89 & 0.86 & 7.24 & 0.20 & 2.90 & 0.72 \\
\hline
\end{tabular}


Table 5. Causality tests (cont.)

\begin{tabular}{|c|c|c|c|c|c|c|c|c|c|}
\hline \multicolumn{2}{|l|}{ Model with } & \multicolumn{2}{|l|}{ FM } & \multicolumn{2}{|l|}{ FMD } & \multicolumn{2}{|l|}{ FMA } & \multicolumn{2}{|l|}{$\overline{\text { FME }}$} \\
\hline Equation & Excluded & chi2 & Prob $>$ chi2 & chi2 & Prob $>$ chi2 & chi2 & Prob >chi2 & chi2 & Prob>chi2 \\
\hline$\overline{\Delta \mathrm{CO} 2}$ & $\Delta$ Income & $3.94^{* *}$ & 0.05 & $4.63^{* *}$ & 0.03 & $6.00^{* * *}$ & 0.01 & $5.24^{* *}$ & 0.02 \\
\hline$\triangle \mathrm{CO} 2$ & $\Delta$ Energy & 3.38 & 0.07 & 3.23 & 0.07 & $4.86^{* *}$ & 0.03 & $3.89^{* *}$ & 0.05 \\
\hline$\Delta \mathrm{CO} 2$ & $\Delta$ Industry & $5.71^{* *}$ & 0.02 & $6.84^{* * *}$ & 0.01 & $7.78^{* * *}$ & 0.01 & $7.01^{* * *}$ & 0.01 \\
\hline$\Delta \mathrm{CO} 2$ & $\Delta$ Trade & 1.23 & 0.27 & 3.22 & 0.07 & 0.20 & 0.66 & 1.38 & 0.24 \\
\hline$\Delta \mathrm{CO} 2$ & $\Delta \mathrm{FD}$ & 0.05 & 0.82 & 2.42 & 0.12 & 1.00 & 0.32 & 0.34 & 0.56 \\
\hline$\triangle \mathrm{CO} 2$ & ALL & 10.37 & 0.07 & $13.48^{* *}$ & 0.02 & $11.62^{* *}$ & 0.04 & 10.75 & 0.06 \\
\hline$\overline{\Delta \text { Income }}$ & $\Delta \mathrm{CO} 2$ & $5.55^{* *}$ & 0.02 & $7.69^{* * *}$ & 0.01 & $6.20^{* * *}$ & 0.01 & $7.36^{* * *}$ & 0.01 \\
\hline$\Delta$ Income & $\Delta$ Energy & 2.06 & 0.15 & 2.99 & 0.08 & 1.57 & 0.21 & 3.50 & 0.06 \\
\hline$\Delta$ Income & $\Delta$ Industry & 0.15 & 0.70 & 1.19 & 0.27 & 0.56 & 0.46 & 0.44 & 0.51 \\
\hline$\Delta$ Income & $\Delta$ Trade & 0.33 & 0.56 & 0.13 & 0.72 & 0.02 & 0.89 & 0.54 & 0.46 \\
\hline$\Delta$ Income & $\Delta \mathrm{FD}$ & $6.48^{* * *}$ & 0.01 & 3.15 & 0.08 & 1.57 & 0.21 & 2.23 & 0.14 \\
\hline$\Delta$ Income & ALL & $21.37^{* * *}$ & 0.00 & $16.79 * * *$ & 0.01 & $14.61^{* * *}$ & 0.01 & $15.52^{* * *}$ & 0.01 \\
\hline$\Delta$ Energy & $\Delta \mathrm{CO} 2$ & $4.18^{* *}$ & 0.04 & 3.38 & 0.07 & $6.22 * * *$ & 0.01 & $4.40^{* *}$ & 0.04 \\
\hline$\Delta$ Energy & $\Delta$ Income & 0.02 & 0.89 & 0.01 & 0.94 & 0.56 & 0.46 & 0.01 & 0.94 \\
\hline$\Delta$ Energy & $\Delta$ Industry & 0.00 & 0.99 & 0.03 & 0.86 & 0.07 & 0.79 & 0.00 & 0.98 \\
\hline$\Delta$ Energy & $\Delta$ Trade & 0.11 & 0.74 & 0.74 & 0.39 & 0.09 & 0.76 & 0.42 & 0.52 \\
\hline$\Delta$ Energy & $\Delta \mathrm{FD}$ & 0.20 & 0.65 & 0.45 & 0.50 & 2.49 & 0.11 & 0.37 & 0.54 \\
\hline$\Delta$ Energy & ALL & 5.23 & 0.39 & 5.52 & 0.36 & 7.87 & 0.16 & 5.42 & 0.37 \\
\hline$\Delta$ Industry & $\triangle \mathrm{CO} 2$ & $5.78^{* *}$ & 0.02 & $7.79^{* * *}$ & 0.01 & $6.61^{* * *}$ & 0.01 & $6.44^{* * *}$ & 0.01 \\
\hline$\Delta$ Industry & $\Delta$ Income & 1.93 & 0.17 & 3.63 & 0.06 & 2.21 & 0.14 & 2.92 & 0.09 \\
\hline$\Delta$ Industry & $\Delta$ Energy & $4.06^{* *}$ & 0.04 & 5.11 & 0.02 & $3.78^{* *}$ & 0.05 & 5.38 & 0.02 \\
\hline$\Delta$ Industry & $\Delta$ Trade & 0.14 & 0.71 & 0.01 & 0.93 & 0.00 & 0.98 & 0.13 & 0.71 \\
\hline$\Delta$ Industry & $\Delta \mathrm{FD}$ & 1.63 & 0.20 & 0.05 & 0.82 & 0.18 & 0.67 & 2.71 & 0.10 \\
\hline$\Delta$ Industry & ALL & $16.37^{* * *}$ & 0.01 & $14.11^{* *}$ & 0.02 & $14.29^{* * *}$ & 0.01 & $17.89^{* * *}$ & 0.00 \\
\hline$\Delta$ Trade & $\Delta \mathrm{CO} 2$ & 0.19 & 0.67 & 0.60 & 0.44 & 0.67 & 0.41 & 0.35 & 0.55 \\
\hline$\Delta$ Trade & $\Delta$ Income & 0.21 & 0.65 & 0.01 & 0.93 & 0.00 & 0.99 & 0.01 & 0.91 \\
\hline$\Delta$ Trade & $\Delta$ Energy & 0.15 & 0.70 & 0.41 & 0.52 & 0.32 & 0.57 & 0.53 & 0.47 \\
\hline$\Delta$ Trade & $\Delta$ Industry & 0.14 & 0.71 & 0.02 & 0.90 & 0.00 & 0.95 & 0.12 & 0.73 \\
\hline$\Delta$ Trade & $\Delta \mathrm{FD}$ & 3.10 & 0.08 & 1.19 & 0.28 & 0.12 & 0.73 & 3.20 & 0.07 \\
\hline$\Delta$ Trade & ALL & 4.30 & 0.51 & 2.33 & 0.80 & 1.22 & 0.94 & 4.41 & 0.49 \\
\hline$\Delta \mathrm{FD}$ & $\triangle \mathrm{CO} 2$ & 0.08 & 0.78 & 1.27 & 0.26 & 0.07 & 0.80 & 0.00 & 0.99 \\
\hline$\Delta \mathrm{FD}$ & $\Delta$ Income & 1.41 & 0.24 & 2.52 & 0.11 & 0.71 & 0.40 & 1.29 & 0.26 \\
\hline$\Delta \mathrm{FD}$ & $\Delta$ Energy & 0.90 & 0.34 & 0.48 & 0.49 & 1.33 & 0.25 & 2.52 & 0.11 \\
\hline$\Delta \mathrm{FD}$ & $\Delta$ Industry & 1.90 & 0.17 & 0.75 & 0.39 & 1.42 & 0.23 & 2.95 & 0.09 \\
\hline$\Delta \mathrm{FD}$ & $\Delta$ Trade & 3.27 & 0.07 & 0.79 & 0.37 & 0.02 & 0.90 & 2.27 & 0.13 \\
\hline$\Delta \mathrm{FD}$ & ALL & 8.13 & 0.15 & 5.51 & 0.36 & $15.92^{* * *}$ & 0.01 & $12.56^{* *}$ & 0.03 \\
\hline
\end{tabular}

Notes: ${ }^{* *},{ }^{* * *}$ denote significant levels at $5 \%$ and $1 \%$ respectively. All variables are tested in logarithms forms. 


\subsection{Long-run cointegration}

Next, the finding of cointegration testing are summarized in Table 6

Table 6. Co-integration tests

\begin{tabular}{|c|c|c|c|c|}
\hline $\begin{array}{c}\text { Model } f(C 02)=f(\text { income, } \\
\text { income^ } 2 \text {, energy, } \\
\text { industry, trade, FD) with } \\
\text { FD as }\end{array}$ & Rank & $\begin{array}{c}\text { Trace } \\
\text { statistic }\end{array}$ & $\begin{array}{l}5 \% \text { critical } \\
\text { value }\end{array}$ & Conclusion \\
\hline \multirow[t]{2}{*}{ OFD } & $\begin{array}{l}0 \\
1\end{array}$ & $\begin{array}{c}144.2 \\
92.54^{*}\end{array}$ & $\begin{array}{l}124.2 \\
94.15\end{array}$ & $\begin{array}{l}\text { Cointegration at } \\
\text { rank } 1\end{array}$ \\
\hline & 2 & 56.93 & 68.52 & \\
\hline \multirow{4}{*}{ FI } & 0 & 143.3 & 124.2 & Cointegration at \\
\hline & 1 & 94.80 & 94.15 & rank 2 \\
\hline & 2 & 58.93* & 68.52 & \\
\hline & 0 & $\mathrm{n} / \mathrm{a}$ & 124.2 & $\mathrm{n} / \mathrm{a}$ \\
\hline \multirow[t]{3}{*}{ FID } & 1 & $\mathrm{n} / \mathrm{a}$ & 94.15 & \\
\hline & 2 & $\mathrm{n} / \mathrm{a}$ & 68.52 & \\
\hline & 0 & 147.5 & 124.2 & Cointegration at \\
\hline \multirow[t]{2}{*}{ FIA } & 1 & $\begin{array}{c}94.06 * \\
5701\end{array}$ & $\begin{array}{l}94.15 \\
68.52\end{array}$ & rank 1 \\
\hline & 0 & 130.6 & 124.2 & Cointegration at \\
\hline \multirow[t]{3}{*}{ FIE } & 1 & $87.44^{*}$ & 94.15 & rank 1 \\
\hline & 2 & 52.87 & 68.52 & \\
\hline & 0 & 148.5 & 124.2 & Cointegration at \\
\hline \multirow[t]{3}{*}{ FM } & 1 & $91.32^{*}$ & 94.15 & rank 1 \\
\hline & 2 & 57.69 & 68.52 & \\
\hline & 0 & 137.6 & 124.2 & Cointegration at \\
\hline \multirow{3}{*}{ FMD } & 1 & $89.17 *$ & 94.15 & rank 1 \\
\hline & 2 & 56.14 & 68.52 & \\
\hline & 0 & 156.1 & 124.2 & Cointegration at \\
\hline \multirow[t]{3}{*}{ FMA } & 1 & 97.06 & 94.15 & rank 2 \\
\hline & 2 & $63.98^{*}$ & 68.52 & \\
\hline & 0 & 151.9 & 124.2 & Cointegration at \\
\hline \multirow[t]{2}{*}{ FME } & 1 & 101.4 & 94.15 & rank 1 \\
\hline & 2 & $67.90 *$ & 68.52 & \\
\hline
\end{tabular}

Notes: ${ }^{*}$ the indicator of the number of cointegrations. All variables are tested in logarithms forms.

Observations show strong evidence of the existence of cointegration among emissions of $\mathrm{CO}_{2}$, income and its square, energy, industry, trade openness, and FD with different proxies except for the case of FID. More interesting, there is evidence of more than one cointegration in the case of FMA. The tests for traditional proxies of FD shows that there are more than one cointegration between CO2 emission with FD1, FD2, FD3, FD4, FD5, respectively. That is, the long-run relationships between variables may follow different regimes in these cases. However, a relatively short-time period (1980-2014) prevents us from estimating the long-run relationships with different regimes. It is devoted to further studies. 
In subject, considering the presence of long-run relationships between these variables and the status of stationarity of all variables at I(1) in the previous section, the vector error correction model (VECM) following the Engle-Granger approach (Engle and Granger, 1987) is applied as a most suitable approach. This approach helps to deal with the cointegration among variables, while it simultaneously deals with multicollinearity issues, which has been documented in the previous section. In estimations for FMA, we include in the estimate with two cointegration. It is same for the estimates with FD1, FD2, FD3, FD4, while the case of FD5 is estimated with three cointegration. All remained cases are estimated with one cointegration. The main results of cointegration equations from VECM estimates are presented in Table 7, while the remained results from VEAM are reported in Supplementary materials. 


\section{Table 7. VECM estimates}

\begin{tabular}{|c|c|c|c|c|c|c|c|c|c|}
\hline Cointegration equations with & OFD & FI & FID & FIA & FIE & $F M$ & FMD & FMA & FME \\
\hline \multicolumn{10}{|l|}{ _ce1 } \\
\hline $\mathrm{CO} 2$ & 1.0000 & 1.0000 & $\mathrm{n} / \mathrm{a}$ & 1.0000 & 1.0000 & 1.0000 & 1.0000 & 1.0000 & 1.0000 \\
\hline Income & $\begin{array}{l}31.55^{* * *} \\
{[4.8982]}\end{array}$ & $\begin{array}{l}0.0000 \\
\text { (omitted) }\end{array}$ & & $\begin{array}{l}46.910^{* * *} \\
{[8.7305]}\end{array}$ & $\begin{array}{l}3.2402 \\
{[6.2854]}\end{array}$ & $\begin{array}{l}29.014^{* * *} \\
{[3.8256]}\end{array}$ & $\begin{array}{l}22.738^{* * *} \\
{[4.4623]}\end{array}$ & $\begin{array}{l}0.0000 \\
\text { (omitted) }\end{array}$ & $\begin{array}{l}1858.9^{* * *} \\
{[684.65]}\end{array}$ \\
\hline Income $^{\wedge} 2$ & $\begin{array}{l}-1.4723^{* * *} \\
{[0.2204]}\end{array}$ & $\begin{array}{l}0.1228^{* *} \\
{[0.0569]}\end{array}$ & & $\begin{array}{l}-2.2083^{* * *} \\
{[0.3983]}\end{array}$ & $\begin{array}{l}-0.1987 \\
{[0.2986]}\end{array}$ & $\begin{array}{l}-1.3605^{* * *} \\
{[0.1734]}\end{array}$ & $\begin{array}{l}-1.088^{* * *} \\
{[0.2074]}\end{array}$ & $\begin{array}{l}0.1004^{*} \\
{[0.0395]}\end{array}$ & $\begin{array}{l}-74.298^{* *} \\
{[31.726]}\end{array}$ \\
\hline Energy & $\begin{array}{l}-1.3685^{* * *} \\
{[0.1504]}\end{array}$ & $\begin{array}{l}-1.619^{*} \\
{[0.9176]}\end{array}$ & & $\begin{array}{l}-1.0201^{* * *} \\
{[0.2729]}\end{array}$ & $\begin{array}{l}-1.266 * * * \\
{[0.1683]}\end{array}$ & $\begin{array}{l}-1.4849^{* * *} \\
{[0.1413]}\end{array}$ & $\begin{array}{l}-1.4487^{* * *} \\
{[0.189]}\end{array}$ & $\begin{array}{l}-1.353^{* * *} \\
{[0.44]}\end{array}$ & $\begin{array}{l}32.793 \\
{[24.377]}\end{array}$ \\
\hline Industry & $\begin{array}{l}0.9718^{* * *} \\
{[0.2638]}\end{array}$ & $\begin{array}{l}-5.3714^{* * *} \\
{[1.3358]}\end{array}$ & & $\begin{array}{l}2.3225^{* * *} \\
{[0.4063]}\end{array}$ & $\begin{array}{l}1.5001^{* * *} \\
{[0.241]}\end{array}$ & $\begin{array}{l}0.8913^{* * *} \\
{[0.2272]}\end{array}$ & $\begin{array}{l}1.4975^{* * *} \\
{[0.2921]}\end{array}$ & $\begin{array}{l}-3.318^{* * *} \\
{[0.7839]}\end{array}$ & $\begin{array}{l}-324.0^{* * *} \\
{[38.97]}\end{array}$ \\
\hline Trade & $\begin{array}{l}-0.0193 \\
{[0.03]}\end{array}$ & $\begin{array}{l}0.3223^{* *} \\
{[0.1451]}\end{array}$ & & $\begin{array}{l}-0.1201^{* *} \\
{[0.0482]}\end{array}$ & $\begin{array}{l}0.0468 \\
{[0.0284]}\end{array}$ & $\begin{array}{l}-0.0047 \\
{[0.0247]}\end{array}$ & $\begin{array}{l}-0.0111 \\
{[0.0362]}\end{array}$ & $\begin{array}{l}0.161 * \\
{[0.0907]}\end{array}$ & $\begin{array}{l}0.7462 \\
{[4.0061]}\end{array}$ \\
\hline FD & $\begin{array}{l}-0.4013^{* * *} \\
{[0.0898]}\end{array}$ & $\begin{array}{l}-0.0299 \\
{[0.4991]}\end{array}$ & & $\begin{array}{l}-1.0869^{* * *} \\
{[0.2298]}\end{array}$ & $\begin{array}{l}-0.216^{* *} \\
{[0.1027]}\end{array}$ & $\begin{array}{l}-0.1495^{* * *} \\
{[0.0304]}\end{array}$ & $\begin{array}{l}-0.1235^{* * *} \\
{[0.0296]}\end{array}$ & $\begin{array}{l}-0.128^{*} \\
{[0.0674]}\end{array}$ & $\begin{array}{l}-25.62^{* * *} \\
{[3.567]}\end{array}$ \\
\hline _cons & -169.05 & 42.8207 & & -263.57 & -18.71 & -153.1 & -123.07 & 25.4442 & -8650.4 \\
\hline \multicolumn{10}{|l|}{ _ce2 } \\
\hline $\mathrm{CO} 2$ & & 0.0000 & & & & & & 0.0000 & \\
\hline Income & & 1.0000 & & & & & & 1.0000 & \\
\hline Income $e^{\wedge} 2$ & & $\begin{array}{l}-0.0487^{* * *} \\
{[0.0009]}\end{array}$ & & & & & & $\begin{array}{l}-0.0523^{* * *} \\
{[0.0016]}\end{array}$ & \\
\hline Energy & & $\begin{array}{l}0.0059 \\
{[0.0151]}\end{array}$ & & & & & & $\begin{array}{l}-0.0138 \\
{[0.0181]}\end{array}$ & \\
\hline Industry & & $\begin{array}{l}0.1043^{* * *} \\
{[0.022]}\end{array}$ & & & & & & $\begin{array}{l}0.195^{* * *} \\
{[0.0323]}\end{array}$ & \\
\hline Trade & & $\begin{array}{l}-0.0041^{* * *} \\
{[0.0024]}\end{array}$ & & & & & & $\begin{array}{l}-0.0063^{* * *} \\
{[0.0037]}\end{array}$ & \\
\hline FD & & $\begin{array}{l}-0.0219^{* * *} \\
{[0.0082]}\end{array}$ & & & & & & 0.003 & \\
\hline _cons & & -6.0983 & & & & & & -6.3078 & \\
\hline \multicolumn{10}{|l|}{ Equation of: } \\
\hline $\begin{array}{l}\text { _ce1 } \\
\text { _ce2 } \\
\text { _ce3 }\end{array}$ & $332.1^{* * *}$ & $\begin{array}{l}101.8^{* * *} \\
294315^{* * *}\end{array}$ & & $158.4^{* * *}$ & $341.7^{* * *}$ & $377.0^{* * *}$ & $236.4^{* * *}$ & $\begin{array}{l}151.3^{* * *} \\
160458^{* * *}\end{array}$ & $110.2^{* * *}$ \\
\hline \multicolumn{10}{|l|}{ Diagnostic test } \\
\hline Lagrange-multiplier test of lag 1 & 58.54 & 56.83 & & 53.34 & $69.80^{* *}$ & 61.49 & 65.11 & $82.77^{* * *}$ & 52.38 \\
\hline Jarque-Bera test: & chi2 & chi2 & & chi2 & chi2 & chi2 & chi2 & chi2 & chi2 \\
\hline $\mathrm{CO} 2$ & 0.795 & 0.448 & & 0.048 & 0.058 & 0.633 & 0.595 & 0.993 & 0.899 \\
\hline Income & 0.571 & 1.540 & & 2.343 & 3.561 & 0.421 & $7.922^{* *}$ & 4.053 & 0.552 \\
\hline Income $^{\wedge} 2$ & 0.371 & 1.298 & & 2.246 & 0.336 & 1.265 & 0.11 & 3.32 & 0.99 \\
\hline
\end{tabular}




\begin{tabular}{|c|c|c|c|c|c|c|c|c|}
\hline Energy & 0.931 & 0.424 & 0.696 & 4.23 & 2.464 & 1.712 & 5.44 & 0.864 \\
\hline Industry & 0.741 & 0.203 & 0.301 & 0.991 & 0.851 & 0.492 & 0.248 & 0.495 \\
\hline Trade & 1.212 & 1.327 & 0.872 & 1.204 & 1.486 & 0.622 & 1.049 & 1.646 \\
\hline FD & 0.786 & 2.180 & 3.887 & 0.579 & 3.011 & 1.877 & 1.326 & 0.215 \\
\hline All & 5.405 & 7.421 & 10.393 & 10.958 & 10.131 & 13.329 & 16.429 & 5.66 \\
\hline Eigenvalue stability condition (no of unit moduli) & 6 & 5 & 6 & 6 & 6 & 6 & 5 & 6 \\
\hline AIC & -1165 & -1219 & -1196 & -1175 & -1114 & -1074 & -1134 & -1060 \\
\hline BIC & -1143 & -1187 & -1174 & -1153 & -1093 & -1053 & -1102 & -1038 \\
\hline Log likelihood & 596.5 & 630.5 & 611.9 & 601.5 & 571.2 & 551.2 & 588.0 & 544.0 \\
\hline $\mathrm{N}$ & 34 & 34 & 34 & 34 & 34 & 34 & 34 & 34 \\
\hline
\end{tabular}

Notes: standard errors are in [];**,*** are significant levels at 5\%, $1 \%$, respectively; All variables are in logarithms forms. 
The observations show that the income squared in most estimates has a statistically significant negative coefficient in the cointegration model. Since it is the cointegration model of $\mathrm{CO} 2$ emissions with other variables (all are in the same side, while the correction error is in opposite side) so that we can transform the cointegration equation by moving $\mathrm{CO}_{2}$ emission to the side of correction errors and the correction errors is moved in revert. This transformation would help to form the equation of $\mathrm{CO}_{2}$ emissions. In this form of the equation, the square of income would have a significant positive impact on $\mathrm{CO}_{2}$ emissions. This is opposite to the expectation of the EKC on an inverted-U shape relationship between economic development and $\mathrm{CO}_{2}$ emissions. In term of energy consumption, the estimates show consistent statistically significant coefficients, which means consumption of energy has a significant positive impact on emissions of $\mathrm{CO}_{2}$. The results show statistically significant positive coefficients in estimates with OFD, FIA, FIE, FM, and FMD, while it has statistically significant coefficients in estimates with FMA and FME. This means the long-run impacts of industrialization on $\mathrm{CO}_{2}$ emissions are not robust and consistent. In term of trade, the estimates show significant negative coefficients of trade estimates with one cointegrations (OFD, FIE, FIA, FMD, FM, FME and FMA). This means trade liberalisation has a significant positive impact on emissions of $\mathrm{CO}_{2}$. Meanwhile, the estimates with two or three cointegrations show some variations in coefficients of trade openness but mostly negative. At last, the estimates with one cointegration show consistent and negative coefficients of FD (OFD, FIA, FIE, FM, FMD, FMA, FME). This means the increases in financial development have positive impacts on emissions of $\mathrm{CO}_{2}$.

Overall, the estimates of VECM show the long-run positive effects of economic development, consumption of energy and financial development on emissions of $\mathrm{CO}_{2}$. Meanwhile, the impacts of industrialization and trade openness are varied by numbers of cointegrations in estimates and the proxies of financial development.

\section{Conclusions and Policy Implications}

In the context of environmental degradation in Australia, this study has explored the implications of economic and financial development, energy consumption, trade liberalisation and industrialization on emissions of $\mathrm{CO}_{2}$. For inclusiveness, we employed the STIRPAT and EKC frameworks that help to explain the long-term association between the under-analysis variables. The notion of EKC is likely to not hold in Australia. The results in the short run indicate that there is a causal association between economic 
growth, stock market capitalization, industrialization and consumption of energy with $\mathrm{CO}_{2}$ emissions. In the policy context, it implies that to tackle the environmental change and honour the commitments of COP:21, Australia will have to account for the impact of growth, financialisation, industrial and consumption energy on environmental degradation. The strong causality implies that these variables have a non-trivial impact on the environment. The scales effect occurs as emissions and consumption of energy are enhanced with the growth of the economy, stock market, and industrialization. Therefore, an improvement in energy efficiency is indispensable. Nonetheless, a policy of focusing on the greener sectors of the economy and renewable energy consumption which Australia has been somewhat reluctant in the past are now the important elements of economic and energy policy. Particularly, if Australia wants to honour her COP21 commitments and stop the climate changes which has caused huge damaged to its environment and wildlife.

One of the most significant aspects of this study is to take a very inclusive approach to financialization and considering different dimensions of financial development (such as financial depth, financial efficiency and financial access) on $\mathrm{CO}_{2}$ emissions. This has been particularly helpful in gaining a deeper insight into the crucial factors driving environmental degradation. The results indicate a strong long-run association with various regimes between different financial development proxies (credit provided by the financial sector, credit to the private sector; credit to the private sector by banks; stocks traded value; stock market capitalization of listed firm; and financial market access index) and emissions of carbon. These findings obtained by taking a very comprehensive view of the financialisation process implies that the Australian financial sector has a crucial role to play in the environmental sustainability of Australia. Specifically, the financial activity shall account for the environmental aspect and financial resources shall be allocated to the environmentally sustainable sector. The long-run estimates of VECM are consistent with the short-run which provides further support to inferences. Contrary to the expectation of having an inverted U-shape relation between the growth of the economy and degradation of environment or EKC, economic growth showed a continuously positive impact on $\mathrm{CO}_{2}$ emission. In the policy context, this implied the perpetual growth and myopic policies of focusing only on the economic growth will be devastating for the Australian environment. 
In addition to the economic growth, trade openness, energy consumption, and financial development are main factors driving the increase in $\mathrm{CO}_{2}$ emissions in Australia. Particularly, our comprehensive approach to analysing the impact of various aspects of financial development manifests the important of financialisation in Australian environmental degradation. In contrast, industrialization has no statistically significant impact on $\mathrm{CO}_{2}$ emission in the long run. This shall not be interpreted as no environmental consequences in the short-run which can then have long-run implications. In sum, the overarching analyses provide deeper understandings of the main factors that degrade the quality of the environment and are triggering a sombre existential threat to both human and wildlife in Australia. While a robust economy, an advanced stock market, and trade openness of Australia have been leading to a higher demand for energy and ultimately a degradation in the environment. The economic prosperity has come at a very high ecological cost. Concomitantly, in the policy context and to honour its COP21 commitments, it is advisable that there should be strict and selective environmentally friendly economic and financial policies concerning green and renewable energy to achieve sustainable economic development. 


\section{Reference}

Abbasi, F., Riaz, K. (2016). CO 2 emissions and fi nancial development in an emerging economy : An augmented VAR approach. Energy Policy, 90, 102-114.

Acaravci, A., Ozturk, I. (2010). On the relationship between energy consumption, CO2 emissions and economic growth in Europe. Energy, 35(12), 5412-5420.

Adams, S., Klobodu, E. K. M. (2018). Financial development and environmental degradation: Does political regime matter? J. Clean. Prod., 197, 1472-1479.

Adom, P., Bekoe, W., Amuakwa-mensah, F., Mensah, J. T., \& Botchway, E. (2012). Carbon dioxide emissions, economic growth, industrial structure, and technical ef fi ciency: Empirical evidence from Ghana, Senegal , and Morocco on the causal dynamics. Energy, 47, 314-325.

Al-mulali, U., Normee, C., Che, B., Gholipour, H. (2012). Exploring the bi-directional long run relationship between urbanization, energy consumption, and carbon dioxide emission. Energy, 46(1), 156-167.

Al-mulali, U., Ozturk, I. (2016). The investigation of environmental Kuznets curve hypothesis in the advanced economies : The role of energy prices. Renew. Sust. Energ. Rev., $54,1622-1631$.

Alam, M., Begum, I., Buysse, J., Rahman, S., Huylenbroeck, G. (2011). Dynamic modeling of causal relationship between energy consumption, CO 2 emissions and economic growth in India. Renew. Sust. Energ. Rev., 15(6), 3243-3251.

Alfaro, L., Kalemli-ozcan, S., Sayek, S. (2009). FDI , productivity and financial development. World Econ., 32, 111-135.

Álvarez-herránz, A., Balsalobre, D., María, J., \& Shahbaz, M. (2017). Energy innovationsGHG emissions Nexus : Fresh empirical evidence from OECD Countries. Energy Policy, 101, 90-100.

Andreoni, J., Levinson, A. (2001). The simple analytics of the environmental Kuznets curve. J. Public Econ, 80, 269-286.

Antweiler, W., Copeland, B., Taylor, S. (2001). Is Free Trade Good for the Environment? Am Econ Rev. 91, 877-908.

Apergis, N., Payne, J. E. (2011). A dynamic panel study of economic development and the electricity consumption-growth nexus. Energy Econ., 33(5), 770-781.

Artur, T., Bhaskara, B. R. (2010). Do economic, financial and institutional developments mattaer for environmental degradation?Evidence from transitional economies. Energy Econ., 32, 137-145.

Aziz, A. . (2011). On the causal links between energy consumption and economic growth in Malaysia. Int. Rev. Bus. Res. Pap., 7(6), 180-189.

Baek, J. (2016). Short communication A new look at the FDI - income - energy environment nexus : Dynamic panel data analysis of ASEAN. Energy Policy, 91, 22-27.

Bakhsh, K., Rose, S., Ali, M. F., Ahmad, N., Shahbaz, M. (2017). Economic growth, CO2 
emissions, renewable waste and FDI relation in Pakistan: New evidences from 3SLS. J. Environ. Manage., 196, 627-632.

Barbier, E. B. (1997). Introduction to the Environmental Kuznets Curve special issue, Environment and Development. Economic growth and the environment: whose growth? Whose environment? World. Environ Dev Econ, 2(4), 369-381.

Begum, R., Sohag, K., Mastura, S., Jaafar, M. (2015). CO 2 emissions , energy consumption , economic and population growth in Malaysia. Renew. Sust. Energ. Rev., 41, 594-601.

Behera, S. R., Dash, D. P. (2017). The e ff ect of urbanization, energy consumption , and foreign direct investment on the carbon dioxide emission in the SSEA ( South and Southeast Asian ) region. Renew. Sust. Energ. Rev., 70, 96-106.

Bekhet, H. A., Matar, A., Yasmin, T. (2017). CO2 emissions, energy consumption, economic growth, and financial development in GCC countries: Dynamic simultaneous equation models. Renew. Sust. Energ. Rev., 70, 117-132.

Belke, A., Dobnik, F., Dreger, C. (2011). Energy consumption and economic growth : New insights into the cointegration relationship. Energy Econ., 33(5), 782-789.

Bokpin, G. A. (2017). Foreign direct investment and environmental sustainability in Africa : The role of institutions and governance. Res. Int. Bus. Finance, 39, 239-247.

Canh, N. P., Thanh, S. D. (2020). Financial development and the shadow economy: A multidimensional analysis. Economic Analysis and Policy.

Canh, N. P., Thong, N. T. (2020). Nexus between financialisation and natural resources rents: Empirical evidence in a global sample. Resour. Policy, 66, 101590.

Carvalho, T., Santiago, F., Perobelli, F. (2013). International trade and emissions : The case of the Minas Gerais state - 2005. Energy Econ., 40, 383-395.

Chandran, V. G. R., Foon, C. (2013). The impacts of transport energy consumption, foreign direct investment and income on CO 2 emissions in ASEAN-5 economies. Renew. Sust. Energ. Rev., 24, 445-453.

Charfeddine, L., Ben, K. (2016). Financial development and environmental quality in UAE : Cointegration with structural breaks. Renew. Sust. Energ. Rev., 55, 1322-1335.

Çoban, S., Topcu, M. (2013). The nexus between fi nancial development and energy consumption in the EU : A dynamic panel data analysis. Energy Econ., 39, 81-88.

Copeland, B. R., Taylor, M. S. (1994). North-south trade and the environment. Q. J. Econ, 109, 755-787.

Copeland, B. R., Taylor, M. S. (2001). International trade and the environment: a framework for analysis.

Dafermos, Y. Nikolaidi, M. Galanis, G. (2018) Climate Change, Financial Stability and Monetary Policy, Ecolo. Econ., 152,219-234.

Dasgupta, S., Hong, J. H., Laplante, B., Mamingi, N. (2004). Disclosure of environmental violations and stock market in the Republic of Korea. Ecol. Econ., 58(4), 759-777. 
Dickey, D. A., Fuller, W. A. (1979). Distribution of the estimators for autoregressive time series with a unit root. J Am Stat Assoc, 74(366a), 427-431.

Dietz, T., Rosa, E. A. (1997). Effects of population and affluence on CO2 emissions. Proceedings of the National Academy of Sciences, 94(1), 175-179.

Dinda, S. (2004). Environmental Kuznets Curve hypothesis: A survey. Ecol. Econ., 49(4), 431-455.

Dogan, E., Seker, F. (2016). The in fl uence of real output, renewable and non-renewable energy, trade and fi nancial development on carbon emissions in the top renewable energy countries. Renew. Sust. Energ. Rev., 60, 1074-1085.

Ehrlich, P. R., Holdren, J. P. (1971). Impact of population growth. Science, 171(3977), 1212-1217.

Elliot, B., Rothenberg, T., \& Stock, J. (1996). Efficient tests of the unit root hypothesis. Econometrica, 64(8), 13-36.

Engle, R. F.,Granger, C. W. (1987). Co-integration and error correction: representation, estimation, and testing. Econometrica, 251-276.

Ferrantino, M. J. (1997). International trade, environmental quality and public policy. The World Econ., 20, 43-72.

Frankel, J., Romer, D. (1999). Does trade cause Growth ? Am Econ Rev, 89, 379-399.

Ghosh, S. (2010). Examining carbon emissions economic growth nexus for India: A multivariate cointegration approach. Energy Policy, 38(6), 3008-3014.

Ghosh, S., Kanjilal, K. (2014). Long-term equilibrium relationship between urbanization , energy consumption and economic activity : Empirical evidence from India. Energy, 66, $324-331$.

Granger, C. W. J. (1969). Investigating Causal Relations by Econometric Models and Crossspectral Methods. Econometrica, 37(3), 424-438. doi:10.2307/1912791

Grether, J., Mathys, N. A., Melo, J. De. (2007). Is trade bad for the environment? Decomposing world-wide SO2 emissions 1990-2000.

Grossman, G. M., Krueger, A. B. (1991). Environmental impacts of a North American free trade agreement. Working Paper No.

Halicioglu, F. (2009). An econometric study of CO 2 emissions, energy consumption , income and foreign trade in Turkey. Energy Policy, 37, 1156-1164.

Hanif, I. (2018). Impact of fossil fuels energy consumption, energy policies, and urban sprawl on carbon emissions in East Asia and the Pacific: A panel investigation. Energy Strateg Rev., 21, 16-24.

Helpman, E. (1998). Explaining the structure of foreign trade: where do we stand? Rev. World Econ., 134, 573-589. 
Hermes, N., Lensink, R. (2003). Foreign direct investment, financial development and economic growth. J Dev Stud, 40(1), 142-163.

Jalil, A., \& Feridun, M. (2011). The impact of growth, energy and fi nancial development on the environment in China : A cointegration analysis. Energy Econo, 33(2), 284-291.

James, A. (2009). CO2 emissions, research and technology transfer in China. Ecol. Econ, 68(10), 2658-2665.

Javid, M., Sharif, F. (2016). Environmental Kuznets curve and fi nancial development in Pakistan. Renew. Sust. Energ. Rev., 54, 406-414.

Jiang, Z., Lin, B. (2012). China's energy demand and its characteristics in the industrialization and urbanization process. Energy Policy, 49, 608-615.

Johansen, S. (1991). Estimation and hypothesis testing of cointegration vectors in Gaussian vector autoregressive models. Econometrica, 1551-1580.

Kalyoncu, H., Gürsoy, F., Göcen, H. (2013). Causality relationship between GDP and energy consumption in Georgia, Azerbaijan and Armenia. International Journal of Energy Economics and Policy, 3(1), 111-117.

Katircioğlu, S. T., Taşpinar, N. (2017). Testing the moderating role of financial development in an environmental Kuznets curve: Empirical evidence from Turkey. Renew. Sust. Energ. Rev., 68, 572-586.

King, R., Levine, R. (1993). Finance and growth : Schumpeter might be right. Q J Econ., 108(3), 717-737.

Kivyiro, P., Arminen, H. (2014). Carbon dioxide emissions, energy consumption , economic growth, and foreign direct investment: Causality analysis for Sub-Saharan Africa. Energy, 74, 595-606.

Kumbarog `u, G., Karali, N., Arikan, Y. (2008). CO 2 , GDP and RET : An aggregate economic equilibrium analysis for Turkey. Energy Policy, 36, 2694-2708.

Kuznets, S. (1955). Economic growth and income inequality. Am. Econ. Rev., 45(1), 1-28. Lantz, V. Feng, Q. (2006), Assessing income, population, and technology impacts on CO2 emissions in Canada: Where's the EKC? Ecol. Econ., 57 (2), 229-238.

Lau, L., Choong, C., Eng, Y. (2014). Investigation of the environmental Kuznets curve for carbon emissions in Malaysia: Do foreign direct investment and trade matter ? Energy Policy, 68, 490-497.

Lin, S., Wang, S., Marinova, D., Zhao, D., Hong, J. (2017). Impacts of urbanization and real economic development on $\mathrm{CO} 2$ emissions in non-high income countries: Empirical research based on the extended STIRPAT model. J. Clean. Prod., 166, 952-966.

Lin, B., Ouyang, X. (2014). Analysis of energy-related CO 2 ( carbon dioxide ) emissions and reduction potential in the Chinese non-metallic mineral products industry. Energy, $68,688-697$.

Lorente, D. B., Álvarez-herranz, A. (2016). Economic growth and energy regulation in the environmental Kuznets curve. Environ. Sci. Pollut. Res., 23, 16478-16494.

Lotfalipour, M. R., Falahi, M. A., Ashena, M. (2010). Economic growth , CO 2 emissions , 
and fossil fuels consumption in Iran. Energy, 35(12), 5115-5120.

Mamun, A., Sohag, K., Hannan, A., Salah, G., Ozturk, I. (2014). Regional differences in the dynamic linkage between $\mathrm{CO} 2$ emissions, sectoral output and economic growth. Renew. Sust. Energ. Rev., 38, 1-11.

Martínez-Zarzoso, I. Maruotti, A. (2011), The impact of urbanization on CO2 emissions: Evidence from developing countries, Ecol. Econ., 70 ( 7)1344-1353.

Mehra, M. K., Das, S. P. (2008). North - South trade and pollution migration : The debate revisited. Environ. Resour. Econ, 40, 139-164.

Mielnik, O., Goldemberg, J. (2002). Foreign direct investment and decoupling between energy and gross domestic product in developing countries. Energy Policy, 30, 87-89.

NASA(2020), The Causes of Climate Change, available at https://climate.nasa.gov/causes/ accessed on $1^{\text {st }}$ September 2020.

Nasir, M. A. Huynh, T. L. D. Tram, H. T. X. (2019), Role of financial development, economic growth \& foreign direct investment in driving climate change: A case of emerging ASEAN, J. Environ. Manage, 242, 131-141.

Pham, N. M., Huynh, T., Nasir, M.A. (2020). Environmental consequences of population, affluence and technological progress for European countries: A Malthusian view. J. Environ. Manage, 260 (January), 110143.

Poumanyvong, P. Kaneko, S. (2010), Does urbanization lead to less energy use and lower CO2 emissions? A cross-country analysis, Ecolog. Econ., 70 (2), 434-444.

Omri, A., Daly, S., Rault, C., Chaibi, A. (2015). Financial development, environmental quality, trade and economic growth: What causes what in MENA countries is. Energy Economics, 48, 242-252.

Omri, A., Kahouli, B. (2014). Causal relationships between energy consumption, foreign direct investment and economic growth: Fresh evidence from dynamic simultaneousequations models. Energy Policy, 67, 913-922.

Ouyang, X., Lin, B. (2014). A projection of future electricity intensity and conservation potential in the Chinese building materials industry. Energy \& Buildings, 84, 268-276.

Ouyang, X., Lin, B. (2015). An analysis of the driving forces of energy-related carbon dioxide emissions in China 's industrial sector. Renew. Sust. Energ. Rev., 45, 838-849.

Ouyang, X., Lin, B. (2017). Carbon dioxide (CO 2) emissions during urbanization : A comparative study between China and Japan. J. Clean. Prod., 143, 356-368.

Ozokcu, S., Ozdemir, O. (2017). Economic growth, energy, and environmental Kuznets curve. Energy Rev, 72, 639-647.

Özokcu, S., Özdemir, Ö. (2017). Economic growth, energy , and environmental Kuznets curve. Renewable and Sustainable Energy Rev., 72(April 2016), 639-647.

Ozturk, I., Acaravci, A. (2013). The long-run and causal analysis of energy, growth, openness and financial development on carbon emissions in Turkey. Energy Econ., 36, 262-267. 
Pao, H.,Tsai, C. (2011). Multivariate Granger causality between CO 2 emissions, energy consumption, FDI ( foreign direct investment ) and GDP (gross domestic product ): Evidence from a panel of BRIC ( Brazil , Russian Federation, India , and China ) countries. Energy, 36(1), 685-693.

Pao, H., Yu, H.,Yang, Y. (2011). Modeling the CO 2 emissions, energy use, and economic growth in Russia. Energy, 36(8), 5094-5100.

Peng, H., Tan, X., Li, Y., Hu, L. (2016). Economic growth, foreign direct investment and CO2 emissions in China: a panel Granger causality analysis. Sustain, 8, 233-248.

Phillips, N. Nogrady, B. (2020). The Cliamte Link to Australia's Fires, Nature, 577, 610612.

Ren, S., Yuan, B., Ma, X., Chen, X. (2014). International trade , FDI ( foreign direct investment ) and embodied CO 2 emissions : A case study of Chinas industrial sectors. China Economic Review, 28, 123-134.

Saboori, B., Sapri, M., Baba, M. (2014). Economic growth , energy consumption and CO 2 emissions in OECD ( Organization for Economic Co-operation and Development )' s transport sector : A fully modi fi ed bi-directional relationship approach. Energy, 66, 150161.

Saboori, B., Sulaiman, J. (2013). CO 2 emissions, energy consumption and economic growth in Association of Southeast Asian Nations ( ASEAN ) countries : A cointegration approach. Energy, 55, 813-822.

Sadorsky, P. (2011). Financial development and energy consumption in Central and Eastern European frontier economies. Energy Policy, 39(2), 999-1006.

Salahuddin, M., Alam, K. (2015). Internet usage , electricity consumption and economic growth in Australia : A time series evidence. elemat. Inform. 32, 32(4), 862-878.

Salahuddin, M., Alam, K., Ozturk, I., Sohag, K. (2018). The e ff ects of electricity consumption, economic growth, fi nancial development and foreign direct investment on CO 2 emissions in Kuwait. Renew. Sust. Energ. Rev., 81, 2002-2010.

Salahuddin, M., Gow, J. (2014). Economic growth, energy consumption and CO 2 emissions in Gulf Cooperation Council countries. Energy, 73, 44-58.

Salahuddin, M., Gow, J., Ozturk, I. (2015). Is the long-run relationship between economic growth , electricity consumption , carbon dioxide emissions and fi nancial development in Gulf Cooperation Council Countries robust? Renew. Sust. Energ. Rev. 51, 51, 317-326.

Sbia, R., Shahbaz, M., Hamdi, H. (2014). A contribution of foreign direct investment , clean energy, trade openness, carbon emissions and economic growth to energy demand in UAE. Econ. Model., 36, 191-197.

Schmalensee, R., Stoker, T., Judson, R. (1998). World carbon dioxide emissions: 19502050. Rev. Econ. Stat. 1998;80:15-27, 80, 15-27.

Seker, F., Murat, H., Cetin, M. (2015). The impact of foreign direct investment on environmental quality : A bounds testing and causality analysis for Turkey. Renew. Sust. Energ. Rev. 52, 52, 347-356. 
Shahbaz, M., Adebola, S., Mahmood, H., Arouri, M. (2013). Does fi nancial development reduce CO 2 emissions in Malaysian economy? A time series analysis. Econ. Model., 35, $145-152$.

Shahbaz, M., Loganathan, N., Muzaffar, A. T., Ahmed, K., Ali Jabran, M. (2016). How urbanization affects $\mathrm{CO} 2$ emissions in Malaysia? the application of STIRPAT model. Renew. Sust. Energ. Rev., 57, 83-93.

Shahbaz, M., Loganathan, N., Sbia, R., Afza, T. (2015). The effect of urbanization, affluence and trade openness on energy consumption: A time series analysis in Malaysia. Renew. Sust. Energ. Rev., 47, 683-693.

Shahbaz, M., Nasir. M.A, Roubaud, D. (2018). Environmental degradation in France : The effects of FDI , fi nancial development, and energy innovations. Energy Econ., 74, 843857.

Shahbaz, M., Hooi, H., Shahbaz, M. (2012). Environmental Kuznets Curve hypothesis in Pakistan : Cointegration and Granger causality. Renewable and Sustainable Energy Rev., 16(5), 2947-2953.

Shahbaz, M., Jam, F., Bibi, S., Loganathan, N. (2016). Multivariate granger causality between $\mathrm{CO} 2$ emissions, energy intensity and economic growth in Portugal: evidence from cointegration and causality analysis. Technol.Econ.Dev.Econ, 22(1), 47-74.

Shahbaz, M., Kumar, A.,Nasir, M. (2013). The effects of financial development, economic growth , coal consumption and trade openness on CO 2 emissions in South Africa. Energy Policy, 61, 1452-1459.

Shahbaz, M., Mutascu, M., Azim, P. (2013). Environmental Kuznets curve in Romania and the role of energy consumption. Renew. Sust. Energ. Rev., 18, 165-173.

Shahbaz, M., Ozturk, I., Afza, T., Ali, A. (2013). Revisiting the environmental Kuznets curve in a global economy. Renew. Sust. Energ. Rev., 25, 494-502.

Shahbaz, M., Shahzad, S., Ahmad, N., Alam, S. (2016). Financial development and environmental quality: The way forward. Energy Policy, 98, 353-364.

Shi, A. (2003), The impact of population pressure on global carbon dioxide emissions, 1975-1996: evidence from pooled cross-country data, Ecol. Econ., 44,1, 29-42.

Sheng, P., Guo, X. (2016). The long-run and short-run impacts of urbanization on carbon dioxide emissions. Econ. Model., 53, 208-215.

Stern, D. I. (2004). The rise and fall of the Environmental Kuznets Curve. World Dev., 32(8), 1419-1439.

Stern, D. I., Cleveland, C. (2004). Energy and Economic Growth. NY: Rensselaer Polytechnic Institute; No. 0410. Troy; Rensselaer Working Papers in Economics

Tadesse, B. S. (2005). Financial development and technology. William Davidson Institute Working Paper, no. 749.

Tamazian, A., Chousa, J., Vadlamannati, K. (2009). Does higher economic and financial development lead to environmental degradation : Evidence from BRIC countries. Energy Policy, 37, 246-253. 
Toman, M., Jemelkova, B. (2003). Energy and economic development: An assessment of the state of knowledge. Energy, 24(4), 93-112.

Torras, M., Boyce, J. K. (1998). Income, inequality, and pollution : a reassessment of the environmental Kuznets Curve. Ecol. Econ., 25, 147-160.

Treasury (2020), The strength of Australia's financial sector, available at https://treasury.gov.au/publication/backing-australian-fintech/the-strength-ofaustralias-financial-sector accessed on $1^{\text {st }}$ September 2020.

Wang, S., Fang, C., Guan, X., Pang, B., Ma, H. (2014). Urbanisation , energy consumption , and carbon dioxide emissions in China: A panel data analysis of China's provinces. Applied Energy, 136, 738-749.

Wei, T (2011), What STIRPAT tells about effects of population and affluence on the environment? Ecol. Econ., 72, 70-74.

York, R. Rosa, E. A. Dietz, T. (2003), STIRPAT, IPAT and ImPACT: analytic tools for unpacking the driving forces of environmental impacts, Ecol. Econ., 46, 3, 351-365.

Zhang, C., Zhou, X. (2016). Does foreign direct investment lead to lower CO 2 emissions ? Evidence from a regional analysis in China. Renew. Sust. Energ. Rev., 58, 943-951.

Zhang, Y. J. (2011). The impact of financial development on carbon emissions: An empirical analysis in China. Energy Policy, 39(09), 2197-2203.

Zhu, H., Duan, L., Yu, K. (2016). The effects of FDI , economic growth and energy consumption on carbon emissions in ASEAN-5 : Evidence from panel quantile regression. Econ. Model., 58, 237-248. 